\title{
The middle to Late Pleistocene herpetofaunal assemblages from the Jarama and Manzanares valleys (Madrid, central Spain): An ecological synthesis
}

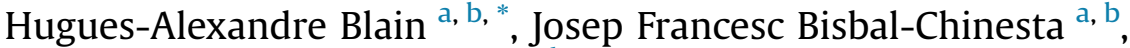 \\ Almudena Martínez-Monzón a, b, Joaquín Panera ${ }^{\mathrm{c}}$, Susana Rubio-Jara ${ }^{\mathrm{c}}$, \\ David Uribelarrea ${ }^{d}$, José Yravedra Saínz de los Terreros ${ }^{e}$, Alfredo Pérez-González ${ }^{\mathrm{c}}$ \\ a IPHES, Institut Català de Paleoecologia Humana i Evolució Social, Zona Educacional 4, Campus Sescelades URV (Edifici W3), 43007 Tarragona, Spain \\ ${ }^{\mathrm{b}}$ Area de Prehistoria, Universitat Rovira i Virgili (URV), Avinguda de Catalunya 35, 43002 Tarragona, Spain \\ c CENIEH, Centro Nacional de Investigación sobre la Evolución Humana, Paseo de la Sierra de Atapuerca 3, 09002 Burgos, Spain \\ d Departamento de Geodinámica, Facultad de Ciencias Geológicas, Universidad Complutense de Madrid, C/ Jose Antonio Novais 2, E-28040 Madrid, Spain \\ e Departamento de Prehistoria, Universidad Complutense de Madrid, C/ Prof. Aranguren s/n, 28040 Madrid, Spain
}

\section{A R T I C L E I N F O}

Article history:

Received 30 November 2017

Received in revised form

26 February 2018

Accepted 4 March 2018

Available online $\mathrm{xxx}$

\section{Keywords:}

Middle and Late Pleistocene

Cold to warm climate

Terrestrial environments

Amphibians

Reptiles

Central Iberian peninsula

\begin{abstract}
A B S T R A C T
The successive fossil amphibian and reptile assemblages from the Middle to Late Pleistocene sites from the Manzanares and Jarama River Valleys (Madrid, central Spain) permitted the reconstruction of part of the climate instability with high-amplitude and rapid shifts of the last $450 \mathrm{ka}$ and their associated landscapes: Áridos-1 (MIS11b), Valdocarros II (MIS8a/7e), Estanque de Tormentas de Butarque ETB-H02 (MIS7d or MIS6), PRERESA (MIS7/6 or MIS5a) and HAT (MIS5a). This work aims to present a regional synthesis of the palaeoclimatic and palaeoenvironmental data obtained from the herpetofaunal assemblages for these two valleys and their influence on the biodiversity during the Pleistocene. As a whole, these archaeo-paleontological localities document a total of 20 taxa ( 8 anurans and 12 reptiles) thus representing $76.9 \%$ of the modern authochtonous herpetofauna of the southeast of the Region of Madrid. Taking as a reference the modern situation in the area, the successive herpetofaunal assemblages permits a hypothetical landscape reconstruction where three different periods are represented with a glacial landscape (ETB-H02), a landscape of transition from cool to temperate climatic conditions (Valdocarros II), and an interglacial landscape (Áridos-1, HAT, PRERESA, and today). Environment is particularly open during dry periods, independently of if it is cold or warm. The main difference between an interglacial and a glacial period is the opposite representation of woodlands vs. moist environments: the last ones being more represented during cold periods than during warm periods. Finally, as documented by the succession from Valdocarros II, periods of transition between cold and warm climate are more forested but at the expense of humid meadows progressively. According to the relation between richness, biodiversity and climatic and environmental factors, a clear correlation appears between reptile richness and woodlands. In a similar way, mean annual precipitation (MAP) is revealed to be the most influent factor on reptile local diversity certainly because of its implications on vegetal cover extension and ecosystem productivity and resources. For amphibians the MAP does not influence dominancy but species richness: anuran richness being higher for lower MAP. Such an unusual pattern is certainly due to the fact that there are no strict forest-dweller anurans within the archaeological assemblages and that most of the anurans present in the sites are well adapted to arid conditions.
\end{abstract}

(c) 2018 Elsevier Ltd and INQUA. All rights reserved.
* Corresponding author. IPHES, Institut Català de Paleoecologia Humana i Evolució Social, Zona Educacional 4, Campus Sescelades URV (Edifici W3), 43007 Tarragona, Spain.

E-mail address: hablain@iphes.cat (H.-A. Blain).

\section{Introduction}

The pattern of the varying terrestrial climatic conditions (deduced from the vegetation development) in southern Europe over the last $450 \mathrm{ka}$ is well known from the long pollen records that 
have been produced for sedimentary sequences from Greece (Tzedakis, 1993, 1994; Tzedakis et al., 1997, 2003, 2006; Fletcher et al., 2013; Sadori et al., 2016), France (Reille and de Beaulieu, 1995; Reille et al., 1998, 2000; Beaulieu de et al., 2001), Spain (Desprat et al., 2009; Valdeolmillos-Rodríguez et al., 2011), and off Portugal (Roucoux et al., 2006). These sequences have revealed a pattern of forested intervals alternating with periods characterized by more open vegetation, varying on time scales of 10.000-100.000 years that represent a response to the Milankovitch-driven global climatic changes recorded in marine isotope records of global ice volume. Deep-ocean sediment cores have also provided more quantitative and better-dated evidence for temperatures and total ice volumes. Due to their incompleteness and dating uncertainties, the correlation and comparison of paleoecological proxies from archaeological sites with such long and detailed pollen or marine records is far from easy. In this context, the study of long (even if mainly fragmentary) archaeological successions in a same environment is a key to understand the differences between global and regional climate evolution and its forcing on flora and fauna. The successive fossil amphibian and reptile assemblages from the Middle to Late Pleistocene sites from the Manzanares and Jarama River Valleys (Madrid, central Spain) permitted the reconstruction of part of the climate instability with high-amplitude and rapid shifts of the last $450 \mathrm{ka}$ and their associated landscapes: Áridos-1 (MIS11b), Valdocarros II (MIS8a/ MIS7e), Estanque de Tormentas de Butarque H-02 (MIS7d or MIS6), PRERESA (MIS7/6 or MIS5a) and HAT (MIS5a). This work aims to present a regional synthesis of the palaeoclimatic and palaeoenvironmental data obtained from the herpetofaunal assemblages for these two valleys and their influence on the biodiversity during the Pleistocene.

\section{Geographical and chronological settings}

The valleys of the Jarama and Manzanares rivers are located in the Tagus basin, within the South Sub-Meseta of the Iberian Peninsula (Fig. 1). These valleys are characterized by the development of a great number of fluvial terraces related to Quaternary climatic oscillations, and both rivers are responsible for the terraces configuration, tectonics (Alia, 1960; Pérez-González, 1980; Silva et al., 1988a,b; Pérez-González, 1994), isostatic rising and blocks adjustment, as well as lithological structural controls (PérezGonzález, 1971).

In the Jarama valley, 19 stepped terraces between +3 and $5 \mathrm{~m}$ and $+190 \mathrm{~m}$ high have been recorded in the high-middle trench of the river. However, in the lower part of the valley, Miocene evaporite-gypsum have facilitated synsedimentary subsidence processes in the underlying karst, affecting terraces lower than $+40 \mathrm{~m}$, which overlap the oldest ones and give rise to the Complex Terrace of Arganda (CTB) (Pérez-González, 1971, 1994; Panera et al., 2011, Fig. 1). This Complex Terrace is made up of successively stacked fluvial sequences, named Arganda I, II, III, which match up with terraces $+30-32 \mathrm{~m},+23-24 \mathrm{~m}$, and $+18-20 \mathrm{~m}$ respectively (Pérez-González and Uribelarrea del Val, 2002; Panera et al., 2011). The sites Áridos-1, Valdocarros II and HAT are located in units Arganda I, Arganda II and Arganda IV respectively.

From a chronological point of view, the Brunhes-Matuyama boundary ( $780 \mathrm{ka}$ ) has been recorded in the Jarama river valley between the $\mathrm{T}+60-65 \mathrm{~m}$, with reverse polarity, and the T+55-60 m, with normal polarity (Pérez-González et al., 2013). The chronological framework of the Complex Terrace of Arganda has been built through biostratigraphy data (López Martínez, 1980; Sesé et al., 2011), amino-acid racemization analysis (AAR; Panera et al., 2011), and ESR dating (Moreno et al., in press). In Arganda I and Arganda II, the micromammals associations from Áridos- 1 and Valdocarros suggest a late Middle Pleistocene age for these deposits. According to the AAR results $(332 \pm 38 \mathrm{ka}$ and $379 \pm 45 \mathrm{ka}$ at Maresa site), ESR data ( $314 \pm 50 \mathrm{ka}$ and $275 \pm 62 \mathrm{ka}$ ), and the climatic requirements of the microfauna assemblage, Arganda I unit belongs to the last part of MIS 11 or early MIS 9, which is consistent with the micromammals evolutionary stage (López-Martínez, 1980). In Arganda II unit, at Valdocarros site, there are two AAR dating ( $254 \pm 47$ and $262 \pm 07 \mathrm{ka}$ ), two ESR ages on quartz (ESR-Al: $255 \pm 31 \mathrm{ka}$; ESR-Ti-Li: $286 \pm 54 \mathrm{ka}$ ), and two ESR ages on teeth $(360 \pm 46 \mathrm{ka}$ and $301 \pm 73 \mathrm{ka})$. These data, together with the herpetofaunal assemblage (Blain et al., 2012a, b) at Valdocarros II, suggest that this unit was deposited between the last part of MIS 8 and the beginning of MIS 7, which is consistent with Valdocarros II rodent evolutionary stage (Sesé et al., 2011). ESR dating suggests that the Arganda III unit was deposited during the MIS 6 (Moreno et al., in press). Finally, at Arganda IV, several numerical ages were obtained by Thermoluminescence TL $(112+36 /-22 \mathrm{ka}$ and $85+18-13 \mathrm{ka}$ at Torreblanca; $74+16-12 \mathrm{ka}$ at HAT) and Optically Stimulated Luminescence OSL $(80 \pm 7 \mathrm{ka}$ at Valdocarros and $74 \pm 5$ ka at Maresa), suggesting that is was deposited during MIS 5 (Panera et al., 2011).

In the Manzanares valley 13 terrace levels, between +4 and $5 \mathrm{~m}$ and $+95 \mathrm{~m}$, have been recorded upstream from Madrid (PérezGonzález, 1994). This system of stepped terraces gives way to a system of complex terraces, named Complex Terrace of Butarque (Goy et al., 1989), which includes the terraces $+25-30 \mathrm{~m},+18-20 \mathrm{~m}$ and $+12-15 \mathrm{~m}$, formed over evaporitic rocks (Pérez-González and Uribelarrea del Val, 2002). These terraces are overlapped and affected by the synsedimentary subsidence, as it has been described in those from the Jarama valley. The terraces higher than $\mathrm{T}+60 \mathrm{~m}$ have been assigned to the Early Pleistocene (Pérez-González and Uribelarrea del Val, 2002; RubioJara et al., 2016). The Complex Terrace of Butarque has been ascribed to the Middle Pleistocene due to the presence of Acheulean industry, which was found to the bottom of the terrace (RubioJara et al., 2016), as well as to the remains of large mammals such as Elephas (Palaeoloxodon) antiquus, Dicerorhinus hemitoechus or Bos primigenius (Sesé and Soto, 2000). The available numerical dates indicate that the visible deposits of the Complex Terrace of Butarque, which to $\mathrm{T}+18-20 \mathrm{~m}$, date from the Middle-Late Pleistocene (Pérez-González et al., 2008; Silva et al., 2008, 2012; DomínguezAlonso et al., 2007; Laplana et al., 2015). The dates range between $133 \mathrm{ka}$ and $134 \mathrm{ka}$ after two dates obtained through TL in Arriaga sand quarry (Silva et al., 2011, 2013), which are consistent with those obtained from the bottom of the Complex Terrace of Butarque at Los Estragales by OSL $(107+39 /-22 \mathrm{ka})$ and TL $(122 \pm 11 \mathrm{ka})$ respectively, and the date obtained from the top of the sequence of Los Estragales by OSL ( $91 \pm 9$ ka; Pérez-González et al., 2008). In the Estanque de Tormentas de Butarque $\mathrm{H}-02$, the TL dates provide values such as $84.6+12.6 /-11.2 \mathrm{ka}$ and $74.9+10.2 /-9.2 \mathrm{ka}$ (Domínguez-Alonso et al., 2007), which have been interpreted as minimum dates owing to the identification of Microtus brecciensis among the micromammals preserved in this site (Laplana et al., 2015). In previous publications, the chronology of the site is attributed to the MIS 6 or MIS 8 (Laplana et al., 2015) and to the MIS 6 (Blain et al., 2017). Here we follow the new proposal by Moreno et al. (this issue) where the ESR age obtained from PRERESA constrain the age of ETB-H02 to be MIS 6 or MIS 7d. PRERESA has an OSL date of $84 \pm 5.6$ ka (Rubio-Jara, 2011; Yravedra et al., 2012). However, recently obtained ESR dates (Moreno et al., in press) suggest a chronological range between $169 \mathrm{ka}$ and $270 \mathrm{ka}$. Taking into account the presence of Microtus cabrerae and the site, and the fact that it has also been recorded in MIS 6 sites (Foury et al., 2016; Laplana et al., 2015), the most probable date of the range given by 


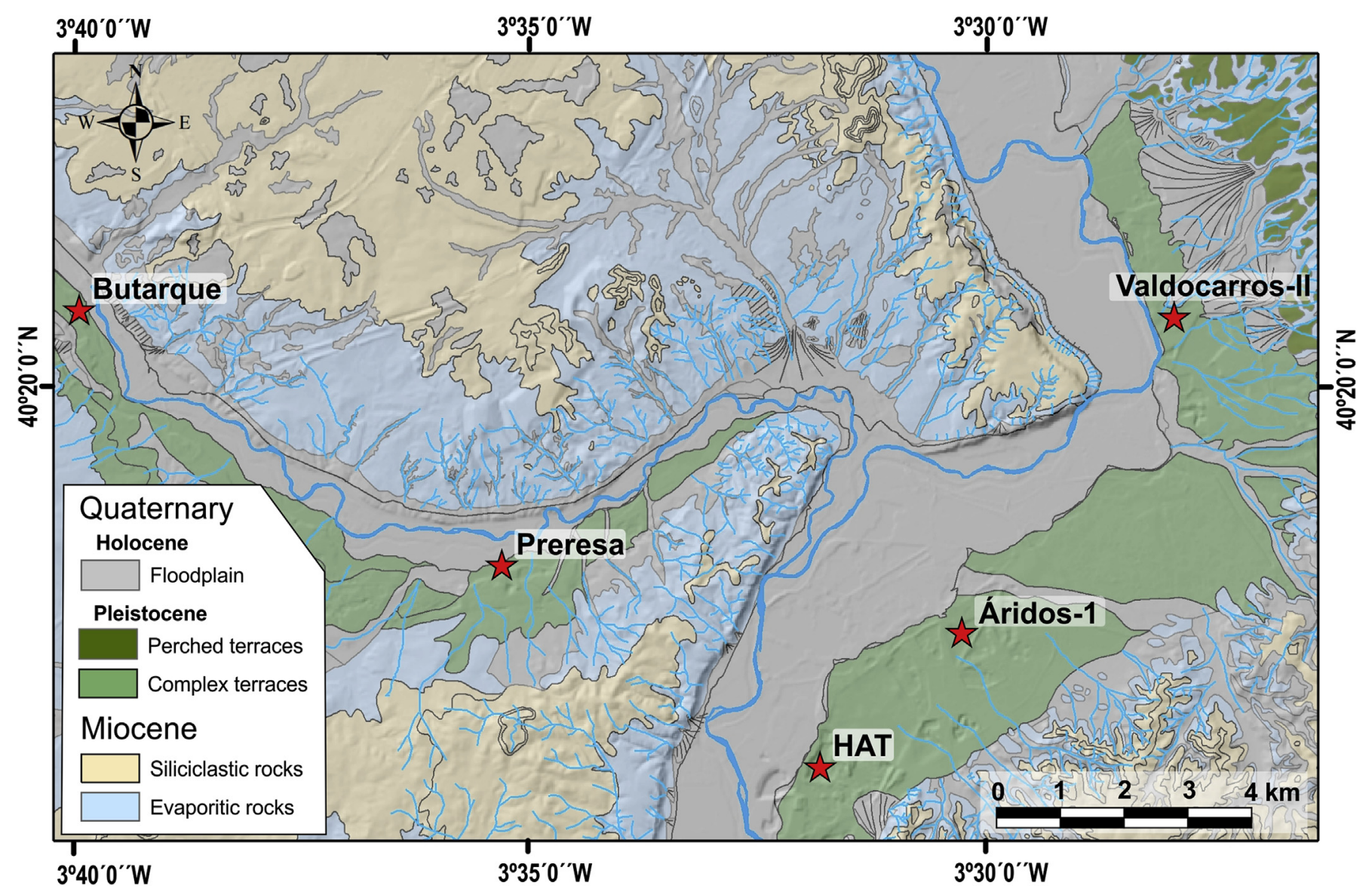

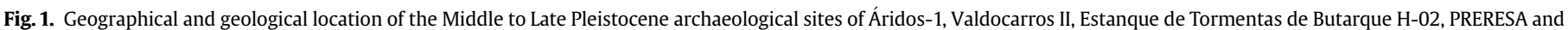
HAT (Madrid, central Spain).

ESR in PRERESA would be early MIS 6 (Moreno et al., in press). Chronological attribution of the archaeological localities under study are synthetized in Table 1.

\section{Material and methods}

The synthesis proposed here lies basically on a critical review of diverse publications describing the herpetofaunal assemblage(s) of the Middle to Late Pleistocene sites of the south-eastern area of Madrid: Áridos-1 (Blain et al., 2014, 2015), Valdocarros II (Blain et al., 2012b), Estanque de Tormentas de Butarque H-02 (Blain et al., 2017) and HAT and PRERESA (Blain et al., 2013). All these publications used the same standardized systematical nomenclature and methodologies thus making easier the comparison between the different sites.

\subsection{Paleoclimatic inferences}

Paleoclimatic interpretations were based on the presence of herpetofaunal species from each site and/or stratigraphical or archaeological level, using the mutual ecogeographic range (MER; Blain et al., 2009, 2016). The MER method involves simply the identification of a geographic region (divided into $10 \times 10 \mathrm{~km}$ UTM squares) in which all of the species present in a given archaeological level currently live. Analysis of the MER of each archaeological level is based on distribution atlases available for Iberian herpetofauna (e.g. Godinho et al., 1999; Pleguezuelos et al., 2004) and various climatic maps of the Iberian Peninsula (Ninyerola et al., 2005). A total of 26 climatic parameters have been calculated for each of these sites, as mean monthly temperature and precipitation, mean annual temperature (MAT) and precipitation (MAP). The record from weather station 3182E of Arganda 'Comunidad' (Ninyerola et al., 2005), located close to the archaeological locality, has been used for comparison with current data.

To measure aridity we used the Gaussen, Lautensach-Meyer, Dantin-Revenga and De Martonne indexes. The Gaussen index $(\mathrm{P}<2 \times \mathrm{T})$ dictates that a month is dry if the pluviometric level for that month $(\mathrm{P})$, measured in $\mathrm{mm}$, is less than twice the value of the average temperature in ${ }^{\circ} \mathrm{C}$ for that month $(\mathrm{T})$. The LautensachMayer index is a classification of climates based on the number of dry months according to the Gaussen index. The Dantin-Revenga index is calculated as $(100 \times \mathrm{MAT} / \mathrm{MAP})$, and the De Martonne aridity index as MAP/(MAT +10$)$, where MAT $=$ mean anual temperature and $\mathrm{MAP}=$ mean annual precipitation.

\subsection{Paleoenvironmental inferences}

Paleoenvironmental reconstruction has been done using the habitat weighting method applied to amphibians and reptiles (see Blain et al., 2008), distributing each taxon in the habitat(s) where it is possible to find them at present in the Iberian Peninsula. Because Spanish Pleistocene amphibians and reptiles are considered specifically identical to modern populations, the current species habitat distribution may be used for the habitat weighting. The habitats were divided into five types: open land in which dry and wet meadows are distinguished, woodland with woodland-margin 
Table 1

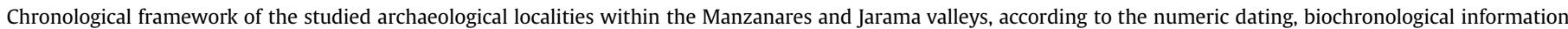
(mainly based on rodents) and MIS correlation.

\begin{tabular}{|c|c|c|c|c|}
\hline Sites & Numeric Dating (method) & & Biochronology & MIS correlation \\
\hline Arganda I at Maresa quarry & $379 \pm 45 \mathrm{BP}$ ka $(\mathrm{AAR})$ & Panera et al., 2011 & middle Middle Pleistocene (López & \\
\hline \multirow[t]{3}{*}{ 〜Áridos-1 (Jarama Valley) } & $332 \pm 38 \mathrm{BP}$ ka (AAR) & & Martínez, 1980; Sesé et al., 2011) & $\begin{array}{l}\text { late MIS 11/early MIS } 9 \text { (Panera } \\
\text { et al., 2011) }\end{array}$ \\
\hline & $211 \pm 54$ ka (ESR Al center) & Moreno et al., in press & & $\begin{array}{l}\text { MIS 11b (Blain et al., 2014, } \\
\text { 2015; this work) }\end{array}$ \\
\hline & $403 \pm 115 \mathrm{ka}$ (ESR Ti center) & & & $\begin{array}{l}\text { MIS } 9 \text { and } 10 \text { (Moreno et al., in } \\
\text { press) }\end{array}$ \\
\hline Arganda I at Valdocarros quarry & $314 \pm 50 \mathrm{ka}($ ESR Al center) & & & \\
\hline Áridos-1 & $275 \pm 62 \mathrm{ka}($ ESR Ti center) & & & \\
\hline \multirow[t]{5}{*}{ Valdocarros II (Jarama Valley) } & $\begin{array}{l}254 \pm 47 \text { ka BP }(\text { AAR }) \\
262 \pm 0.7 \text { ka BP (AAR) }\end{array}$ & Panera et al., 2011 & $\begin{array}{l}\text { last third of the Middle Pleistocene } \\
\text { (Sesé et al., 2011) }\end{array}$ & $\begin{array}{l}\text { late MIS 9/early MIS } 7 \text { (Panera } \\
\text { et al., 2011) }\end{array}$ \\
\hline & $\begin{array}{l}255 \pm 31 \mathrm{ka} \mathrm{BP}(\mathrm{ESR} \text { Al } \\
\text { center })\end{array}$ & Moreno et al., in press & & $\begin{array}{l}\text { MIS 7d/8a (Blain et al., 2012a, } \\
\text { 2012b; this work) }\end{array}$ \\
\hline & $\begin{array}{l}286 \pm 54 \text { ka BP }(\text { ESR Ti } \\
\text { center })\end{array}$ & & & $\begin{array}{l}\text { MIS } 8 \text { and MIS7 (Moreno et al., } \\
\text { in press) }\end{array}$ \\
\hline & $301 \pm 73$ ka BP (US-ESR) & & & \\
\hline & $360 \pm 46$ ka BP (US-ESR) & & & \\
\hline \multirow[t]{6}{*}{ PRERESA (Manzanares Valley) } & $84 \pm 5.6$ ka BP (OSL) & $\begin{array}{l}\text { Rubio-Jara, 2011; } \\
\text { Panera et al., } 2014\end{array}$ & $\begin{array}{l}\text { early Late Pleistocene (Sesé et al., } \\
\text { 2011) }\end{array}$ & \\
\hline & $157 \pm 46 \mathrm{ka}($ ESR Al center) & Moreno et al., in press & & MIS 5a (Blain et al., 2013) \\
\hline & $223 \pm 47($ ESR Al center $)$ & & & $\begin{array}{l}\text { MIS 7/early MIS } 6 \text { (Moreno } \\
\text { et al., in press) }\end{array}$ \\
\hline & $200 \pm 31($ ESR Ti center $)$ & & & MIS $7 / 6$ or $5 a$ (this work) \\
\hline & $206 \pm 42$ ka BP (US-ESR) & & & \\
\hline & $235 \pm 32$ ka BP (US-ESR) & & & \\
\hline \multirow[t]{2}{*}{ ETB-H02 (Manzanares Valley) } & $>84.6+12.6 /-11.2$ & $\begin{array}{l}\text { Domínguez-Alonso } \\
\text { et al., } 2007\end{array}$ & $\begin{array}{l}\text { late Middle Pleistocene (Laplana } \\
\text { et al., 2015) }\end{array}$ & $\begin{array}{l}\text { MIS6 or MIS } 8 \text { (Laplana et al., } \\
\text { 2015) }\end{array}$ \\
\hline & $>74.9+10.2 /-9.2$ & & & $\begin{array}{l}\text { Late MIS } 6 \text { (Blain et al., 2017) } \\
\text { MIS } 6 \text { or 7d (this work) }\end{array}$ \\
\hline HAT (Jarama Valley) & $74+16 /-12.1$ ka BP (TL) & Panera et al., 2005 & $\begin{array}{l}\text { early Late Pleistocene (Sesé et al., } \\
\text { 2011) }\end{array}$ & MIS 5a (Blain et al., 2013) \\
\hline
\end{tabular}

and scrubland areas, areas surrounding water, and rocky areas. Each species was given a maximum possible score of 1.00 , which was broken down according to the habitat preference of that species, so that if an animal occurred in more than one habitat type, its score was proportional to its habitat preference. Scores for higherlevel taxonomic categories (providing no representatives have opposite ecological requirements) were calculated by counting the individual species scores of all the species contained. Family-level groups or groups containing species currently with opposite ecologies (such as lacertids) were disregarded. To avoid large deviations in graphics, strictly aquatic species have been excluded from these analyzes.

The distribution data are from Pleguezuelos and Martínez-Rica (1997), Salvador (1997), Carrascal and Salvador (2002-2016), García-París et al. (2004) and Pleguezuelos et al. (2004). Please note here that some of the habitat percentages have been adapted from the original publications corresponding to more precise information about the local ecology of the species represented as fossil in the different localities.

\subsection{Diversity and species richness}

Diversity was analyzed taking into account two parameters: richness and evenness. Richness corresponds to the number of species in the community represented as S. Evenness constitutes a measure of the relative abundance of species within a community; it represents the opposite of dominance. Simpson's index (D) (Simpson, 1949) was used to measure evenness. In its initial form, Simpson index gave the probability of any two individuals drawn random from an infinitely large community belonging to the same species. The approach of this index for a finite community is:
$D=\sum\left(\frac{n_{i}\left[n_{i}-1\right]}{N[N-1]}\right)$

where $n_{i}$ is the number of individuals for a taxon $i$ and $\mathrm{N}$ the total number of individuals (Magurran and McGill, 2011). Despite of this, Simpson index is usually expressed as the complement of dominance (1-D) so its value, which ranges from 0 to 1 , will rise as the assemblage becomes more even or, what is the same, the homogeneity of the community decreases.

To avoid statistical problems related to different sample sizes, initial values of minimal number of individuals (MNI) were standardized by dividing by their corresponding total sample abundance thus obtaining percentages of MNI. Both, Simpson index (1D) and Richness (S) were obtained using the Paleontological Statistics Program (PAST) (Hammer et al., 2001). Finally, relation with climatic parameters was analyzed with OLS regression models taking on a significance level of $\alpha=0.05$.

\section{Results}

\subsection{Amphibian and reptile assemblages}

Amphibian and reptile fossils recovered from the sites under study here mainly correspond (with a few exceptions in Áridos-1) to disarticulated elements recovered by water-screening the sediments at the different localities (Table 2). Smallest mesh used in all sites was $0.2 \mathrm{~mm}$ in size, thus avoiding any bias during the recovery of these tiny elements. From a taphonomical point of view, these sites have been deposited in still water environment (small ponds or lateral meander of the main river). No important difference between depositional environments has been evidenced, beside 
Table 2

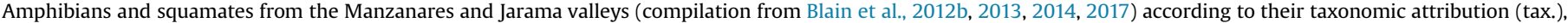

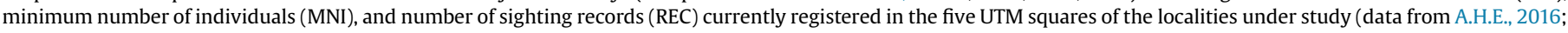
see Supplementary Information Table A1).

\begin{tabular}{|c|c|c|c|c|c|c|c|c|c|c|c|c|c|c|c|}
\hline \multirow[t]{2}{*}{ Species } & \multicolumn{2}{|c|}{ Áridos-1 } & \multicolumn{2}{|c|}{$\begin{array}{l}\text { Vald. II level } \\
2\end{array}$} & \multicolumn{2}{|c|}{$\begin{array}{l}\text { Vald. II level } \\
3\end{array}$} & \multicolumn{2}{|c|}{$\begin{array}{l}\text { Vald. II level } \\
4\end{array}$} & \multicolumn{2}{|c|}{ ETB-H02 } & \multicolumn{2}{|c|}{ PRERESA } & \multicolumn{2}{|l|}{ HAT } & \multirow{2}{*}{$\begin{array}{l}\text { Today } \\
\text { REC }\end{array}$} \\
\hline & $\operatorname{tax}$ & MNI & $\operatorname{tax}$ & MNI & $\operatorname{tax}$ & MNI & $\operatorname{tax}$ & MNI & $\operatorname{tax}$ & MNI & $\operatorname{tax}$ & MNI & $\operatorname{tax}$ & MNI & \\
\hline Pleurodeles waltl & & - & & - & & - & & - & & - & & - & & - & 15 \\
\hline Alytes sp. & aff. & 1 & & - & & 1 & & - & & - & & - & & - & - \\
\hline Alytes obstetricans & & - & & - & & - & & - & & - & & - & & - & 16 \\
\hline Discoglossus galganoi & cf. & 2 & & - & & - & & - & & - & & - & & - & 16 \\
\hline Discoglossus sp. & & - & & - & & - & & - & & 2 & & - & & - & - \\
\hline Pelobates cultripes & & 19 & & 1 & & 4 & & 5 & & 20 & & 17 & & 8 & 15 \\
\hline Pelodytes punctatus & & - & & - & & - & & - & & - & & - & & - & 24 \\
\hline Pelodytes sp. & & - & & - & & 2 & & - & & 1 & & 2 & & 11 & - \\
\hline Bufo spinosus & & 4 & & - & & - & & 1 & & 13 & & 5 & & 1 & 63 \\
\hline Epidalea calamita & & - & & 1 & & 3 & & 7 & & 1 & & 16 & & - & 81 \\
\hline Hyla gr. H. arborea & & - & & 3 & & - & & - & & - & & - & & - & 3 \\
\hline Hyla sp. & & 2 & & - & & - & & - & & - & & 2 & & - & - \\
\hline Pelophylax perezi & & 10 & & 8 & & 2 & & 3 & & 21 & & 17 & & 4 & 86 \\
\hline Emys/Mauremys & & - & & - & & - & & - & & 1 & & - & & 1 & - \\
\hline Emys orbicularis & & 3 & & - & & - & & - & & - & & - & & - & 10 \\
\hline Graptemys pseudogeographica & & - & & - & & - & & - & & - & & - & & - & 1 \\
\hline Mauremys leprosa & & - & & - & & - & & - & & - & & - & & - & 32 \\
\hline Pseudemys nelsonii & & - & & - & & - & & - & & - & & - & & - & 1 \\
\hline Trachemys scripta & & - & & - & & - & & - & & - & & - & & - & 21 \\
\hline Blanus cinereus & & - & & - & & - & & - & & - & & - & & - & 28 \\
\hline Blanus sp. & & - & & - & & - & & - & & - & & - & & 1 & - \\
\hline Chalcides striatus & & - & & - & & - & & 1 & & - & & - & & - & 8 \\
\hline Chalcides sp. & & - & & - & & 1 & & 1 & & - & & - & & - & - \\
\hline Tarentola mauritanica & & - & & - & & - & & - & & - & & - & & - & 33 \\
\hline Acanthodactylus erythrurus & & - & & - & & - & & - & & - & & - & & - & 16 \\
\hline Podarcis virescens & & - & & - & & - & & - & & - & & - & & - & 94 \\
\hline Psammodromus algirus & & - & & 4 & & 46 & & 51 & & - & cf. & 18 & & - & 50 \\
\hline Psammodromus hispanicus & cf. & 18 & & - & & - & & - & & - & & - & & - & 36 \\
\hline Timon lepidus & & 9 & & 5 & & 6 & & 3 & & - & & 5 & & 3 & 64 \\
\hline Coronella girondica & & 2 & & 2 & & 3 & & 4 & & 2 & & - & & - & 7 \\
\hline Coronella sp. & & - & & - & & - & & - & & - & & 1 & & 1 & - \\
\hline Macroprotodon brevis & & - & & - & & - & & - & & - & & - & & - & 8 \\
\hline Malpolon monspessulanus & & - & & - & & - & & - & & - & & - & & - & 40 \\
\hline Natrix maura & & - & & 1 & & 5 & & 4 & & - & & 1 & & - & 15 \\
\hline Natrix natrix & & 3 & & - & & - & & - & & 6 & & - & & - & - \\
\hline Rhinechis scalaris & & 5 & cf. & 1 & & - & & - & & - & & - & & - & 68 \\
\hline Vipera latastei & & - & & - & & - & & - & & - & & 7 & & 1 & - \\
\hline Vipera sp. & & - & & 1 & & 2 & & - & & - & & - & & - & - \\
\hline Total & & 78 & & 27 & & 75 & & 80 & & 67 & & 91 & & 31 & 836 \\
\hline
\end{tabular}

maybe the distance from the site to the main river, thus influencing the proportion of aquatic taxa in the assemblages. Accumulation of the small vertebrate remains has been demonstrated to be the consequence of both in situ mortality (burrowing toads and aquatic taxa) as well as by the action of opportunistic predators (birds of prey or small carnivores) (Blain et al., 2012b, 2013, 2014, 2017).

As a whole, the archaeo-paleontological localities of Áridos-1, Valdocarros II, Estanque de Tormentas de Butarque H-02, HAT and PRERESA document a total of 20 taxa (8 anurans and 12 reptiles) thus representing $76.9 \%$ of the modern autochthonous herpetofauna of the southeast of the Region of Madrid: $88.9 \%$ of the amphibians, $50 \%$ of the turtles, and $80 \%$ of the squamates. Taxa that are living today in the area but not represented in the fossil localities are Pleurodeles waltl, various exotic turtles (Graptemys pseudogeographica, Pseudemys nelsonii and Trachemys scripta), Tarentola mauritanica, Acanthodactylus erythrurus, Podarcis virescens, Macroprotodon brevis and Malpolon monspessulanus. Besides allochtonous turtles that have recently been introduced in the southeast of the Region of Madrid (Barquero, 2001; Pleguezuelos, 2004; Mingot et al., 2003), many of these absences can be considered significant as these taxa are well represented today in the area (with the exception of the snake $M$. brevis; Table 2). The depositional environment can also be evoked for some squamates as the gecko T. mauritanica, and maybe also Podarcis and Acanthodactylus, that are rather unlikely found as fossil in fluvio-lacustrine localities.

Finally the only remains that may represent a species absent today from this area is Hyla sp. from Áridos-1 and PRERESA. The fossil remains of Hyla represented in these sites do not match the Iberian species $H$. molleri, but coincide better with the morphology of the African immigrant $H$. meridionalis (Blain et al., 2013, 2014). This species has been suggested, from mitochondrial DNA analyses, to be a very recent colonizer of southwestern Europe and the Canary Islands from Morocco (Recuero et al., 2007). In the Iberian Peninsula, this species is currently well represented in the southwestern part, quite reaching the Region of Madrid in the North and reaching in the East the littoral of the Province of Almeria and the north of the Province of Murcia. Populations from Catalonia and southern France have been supposedly introduced recently (Recuero et al., 2007). The fossils from Áridos-1 (and maybe also from PRERESA) might represent a previous dispersal event of this species onto the Iberian Peninsula, as it has been suggested for the Early Pleistocene locality of Barranco León (Guadix-Baza Basin, southeastern Spain; Blain and Bailon, 2010, Blain et al., 2011, 2016).

\subsection{Paleoclimatic data}

In the site of Áridos-1, the application of MER methodology to the herpetofaunal assemblage gives an overlap of 34 UTM squares, 
occurring in central and southwestern Spain. The estimated MAT is $15.6 \pm 2.7^{\circ} \mathrm{C}$, and the MAP is $682 \pm 140 \mathrm{~mm}$ (Fig. 2, Table 3). The climate at the time of Áridos- 1 has been defined as warm with warm summer and temperate winter. Rainfall is low and its distribution irregular, occurring principally during winter and late autumn. The calculated aridity indexes suggest a semi-arid (or semi-humid according to the De Martonne index), continental Mediterranean climate with four dry months in summer. In comparison with the current climatic data from the Arganda 'Comunidad' $3182 \mathrm{E}$ weather station, the estimated MAT for Áridos- 1 is warmer $\left(\triangle \mathrm{MAT}=+1.7^{\circ} \mathrm{C}\right)$. The increase in temperature is higher for winter $\left(\Delta \mathrm{MTC}=+3.6^{\circ} \mathrm{C}\right)$ than for summer $\left(\Delta \mathrm{MTW}=+0.9^{\circ} \mathrm{C}\right)$. The total amount of rainfall is higher $(\Delta \mathrm{MAP}=+223.9 \mathrm{~mm})$ than the current level in Madrid. This is clearly supported by the De Martonne aridity index, indicating that today conditions are more arid than during MIS 11b. Nevertheless, differences can be seen in the distribution of precipitation over the year, with more abundant precipitation during the winter months, at the beginning of spring and at the end of fall (from October to March) and less precipitation than today during the summer months and at the end of spring (from May to August). This suggest stronger rainfall seasonality between winter and summer than is currently the case, with slightly warmer and dryer summers by contrast with much warmer and rainier winters.

The overlaps obtained for Valdocarros II (levels 2, 3 and 4) correspond to various areas within the Iberian Peninsula, thus suggesting different climatic conditions between the different levels of this site.

For level 2, the overlap gives 67 UTM squares, mainly occurring in central and southwestern Spain, yet they occur more abundantly in the north. This is mainly due to the occurrence of Hyla gr. arborea, which is currently absent from large areas in the south of the Iberian Peninsula (Pleguezuelos et al., 2004). The MAT is $12.1 \pm 2.3^{\circ} \mathrm{C}$, and the MAP is $745 \pm 152 \mathrm{~mm}$ (Fig. 2, Table 3). The climate is relatively cold with a high atmospheric temperature range. The summer is rather warm and the winter is cold, with three months with

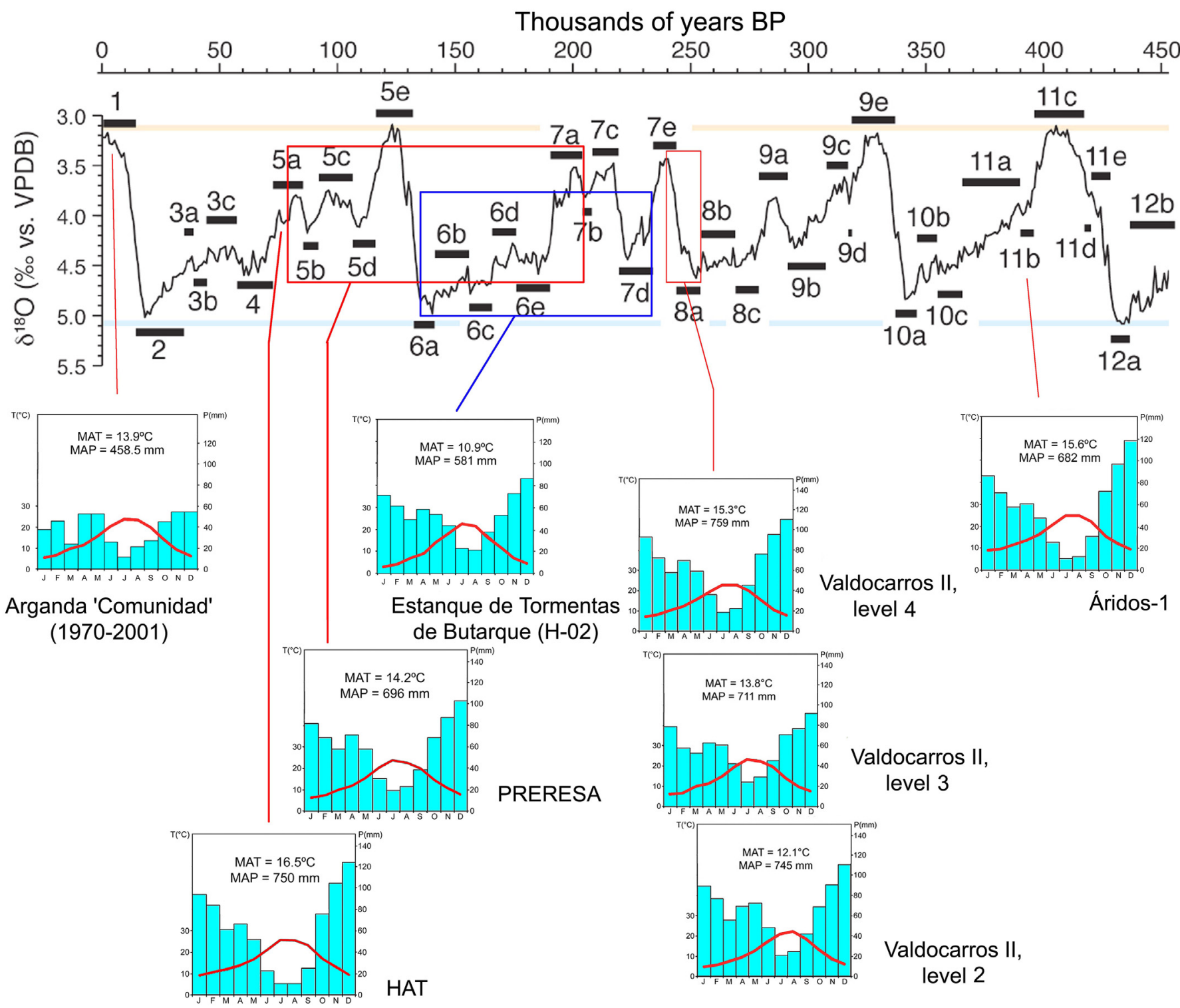

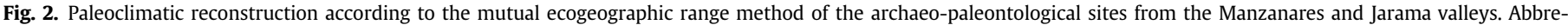

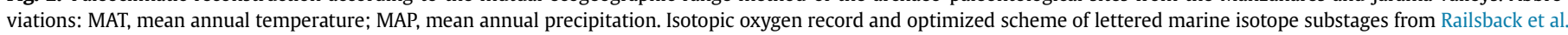
(2015). 
Table 3

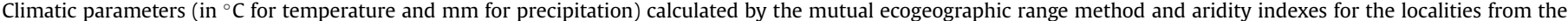

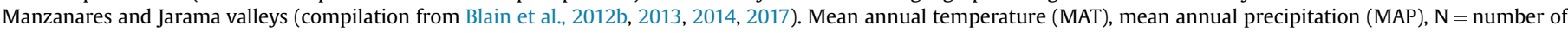

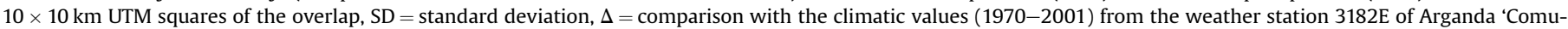
nidad' (Ninyerola et al., 2005).

\begin{tabular}{|c|c|c|c|c|c|c|c|c|c|}
\hline & & Áridos-1 & Vald. II level 2 & Vald. II level 3 & Vald. II level 4 & ETB-H02 & PRERESA & HAT & Today \\
\hline & $\mathrm{N}$ & 34 & 67 & 90 & 145 & 16 & 92 & 45 & \\
\hline \multirow[t]{3}{*}{ MAT } & MEAN & 15.6 & 12.1 & 13.8 & 15.3 & 10.9 & 14.2 & 16.5 & \\
\hline & SD & 2.7 & 2.3 & 3.1 & 2.6 & 2.3 & 3.2 & 2.0 & \\
\hline & $\Delta$ & 1.7 & -1.8 & -0.1 & 1.4 & -3.0 & 0.3 & 2.6 & \\
\hline \multirow[t]{3}{*}{ MTC } & MEAN & 8.8 & 4.2 & 6.4 & 7.2 & 3.1 & 6.4 & 8.7 & \\
\hline & SD & 3.5 & 2.7 & 3.5 & 3.9 & 2.7 & 3.5 & 2.7 & \\
\hline & $\Delta$ & 3.6 & -1.0 & 1.2 & 2.0 & -2.1 & 1.2 & 3.5 & \\
\hline \multirow[t]{3}{*}{ MTW } & MEAN & 24.9 & 22.2 & 23.7 & 23.3 & 22.4 & 24.1 & 25.5 & \\
\hline & SD & 2.3 & 2.6 & 2.0 & 1.9 & 2.1 & 2.1 & 1.5 & \\
\hline & $\Delta$ & 0.9 & -1.5 & -0.3 & -0.7 & -1.6 & -0.1 & 1.5 & \\
\hline \multirow[t]{3}{*}{ MAP } & MEAN & 682 & 745 & 711 & 759 & 581 & 693 & 750 & \\
\hline & SD & 140 & 152 & 169 & 163 & 40 & 131 & 137 & \\
\hline & $\Delta$ & 223.5 & 286.5 & 252.5 & 300.5 & 122.5 & 234.5 & 291.5 & \\
\hline \multicolumn{2}{|c|}{$\begin{array}{l}\text { Gaussen Index } \\
\text { Lautensach- } \\
\text { Mayer Index }\end{array}$} & $\begin{array}{l}\text { Mediterranean } \\
\text { semi-arid }\end{array}$ & $\begin{array}{l}\text { Oceanic } \\
\text { semi-humid }\end{array}$ & $\begin{array}{l}\text { Oceanic } \\
\text { semi-humid }\end{array}$ & $\begin{array}{l}\text { Mediterranean } \\
\text { semi-humid }\end{array}$ & $\begin{array}{l}\text { Oceanic } \\
\text { semi-humid }\end{array}$ & $\begin{array}{l}\text { Mediterranean } \\
\text { semi-arid }\end{array}$ & $\begin{array}{l}\text { Mediterranean } \\
\text { semi-arid }\end{array}$ & $\begin{array}{l}\text { Mediterranean } \\
\text { semi-arid }\end{array}$ \\
\hline \multicolumn{2}{|c|}{$\begin{array}{l}\text { Dantin-Revenga } \\
\text { Index }\end{array}$} & semi-arid & humid & humid & humid & humid & semi-humid & semi-arid & semi-arid \\
\hline \multicolumn{2}{|c|}{$\begin{array}{l}\text { De Martonne } \\
\text { Index }\end{array}$} & semi-humid & humid & subhumid & subhumid & subhumid & semi-arid & semi-humid & semi-arid \\
\hline
\end{tabular}

mean temperatures below $6^{\circ} \mathrm{C}$. Rainfall is low and its distribution is fairly regular, occurring throughout the year (with highest levels during winter) and with two months during summer (July and August) with low rainfall. The aridity indexes suggest a semi-humid to humid, cold, continental Oceanic climate with two dry months in summer.

For the uplying levels 3 and 4, the overlap yields 90 and 145 UTM squares respectively. These overlaps are more extended than for level 2, reaching the Mediterranean seashore in the east for level 3 and in the northeast for level 4. For level 3, the MAT is $13.8 \pm 3.1^{\circ} \mathrm{C}$ and the MAP is $711 \pm 169 \mathrm{~mm}$ (Fig. 2, Table 3 ). The climate is temperate with warm summer and temperate winter. Rainfall is low and its distribution is fairly regular, occurring throughout the year with a similar pattern to that in level 2 but with a lower amount. The aridity indexes suggest a semi-humid to humid, continental Oceanic climate with two dry months in summer.

For level 4, the MAT is $15.3 \pm 2.6{ }^{\circ} \mathrm{C}$, and the MAP is $759 \pm 163 \mathrm{~mm}$ (Fig. 2, Table 3). The climate is warm with a high atmospheric temperature range. Rainfall is low and its distribution is fairly regular, occurring principally during winter and to a lesser extent during spring and late autumn. The aridity indexes suggest a semi-humid to humid, continental Mediterranean climate with three dry months in summer.

In comparison with current climatic data from the Arganda 'Comunidad' 3182E weather station, all the MER-estimated MATs are somewhat higher, excepted for level 2. The level 2 shows the coolest temperature of the sequence; with MAT $1.8^{\circ} \mathrm{C}$ lower than today. Overall, the winter is generally warmer and the summer similar in warmth to current ones. In level 2 , the cooler climatic conditions are mainly linked with a greater decrease in the summer temperature $\left(-1.5^{\circ} \mathrm{C}\right)$ than in the winter temperature $\left(-1.0^{\circ} \mathrm{C}\right)$. The total amount of rainfall is higher than the current level in Madrid. This is well suggested by the values of the De Martonne index, suggesting more humid conditions during the transition from MIS 8 to MIS 7 than today.

For the Estanque de Tormentas de Butarque (H-02) site, the overlap obtained from the herpetofaunal assemblage gives 16 UTM squares occurring in north-central and eastern Spain. The mean value of the MER-estimated MAT is $10.9 \pm 2.3^{\circ} \mathrm{C}$, and for the MAP $581.3 \pm 40.3 \mathrm{~mm}$ (Fig. 2, Table 3). The climate at the time of ETB-
H02 can be defined as cold with a very high atmospheric temperature range. The summer is reasonably warm, and the winter is cold. Rainfall is low, even if higher than today, but its distribution is fairly regular with higher amounts during winter and spring. The aridity indexes suggest a semi-humid (or humid according to the Dantin-Revenga index), continental Mediterranean (transitional to Oceanic) climate with only two dry months in summer (Fig. 2). In comparison with the current climatic data from Arganda 'Comunidad' weather station 3182E, the MER-estimated MAT for ETB-H02 is much colder $\left(\triangle \mathrm{MAT}=-3.0^{\circ} \mathrm{C}\right)$. The decrease in temperature is in evidence for all the seasons of the year. Although the total amount of rainfall is only slightly higher $(\triangle \mathrm{MAP}=+122.8 \mathrm{~mm})$ than the current level in Madrid, the rainfall is more regularly distributed throughout the year, reducing the duration of summer aridity. This is clearly supported by the values of the aridity indexes, which all indicate a semi-humid or humid climate for ETB-H02, whereas current values are characteristic of a semi-arid climate, implying moister conditions in the area during MIS 6 or MIS 7d than today.

At PRERESA the overlap corresponds to 92 UTM squares, distributed on the whole Iberian Peninsula, on an axis oriented south-west-north-east from Atlantic to the Mediterranean seashores, and encompassing the central Meseta. Estimated MAT is $14.2 \pm 3.2^{\circ} \mathrm{C}$ and MAP $693 \pm 131 \mathrm{~mm}$ (Fig. 2, Table 3). The aridity indexes suggest a continental semi-arid Mediterranean climate with three months of dryness during the summer and the beginning of fall (Fig. 2). The comparison with the current climatic data from Arganda 'Comunidad' weather station 3182E shows that the estimated MAT for PRERESA are slightly higher to present values $\left(\triangle \mathrm{MAT}=+0.3^{\circ} \mathrm{C}\right)$. The difference between the temperature of the warmest and coldest months is lower than today, due to the fact that winter temperatures are higher $\left(\triangle \mathrm{MTC}=+1.2^{\circ} \mathrm{C}\right)$ and summer only slightly higher $\left(\Delta \mathrm{MTW}=+0.1{ }^{\circ} \mathrm{C}\right)$, thus suggesting a less pronounced continentality. MAPs remain low for PRERESA even if their total amount are slightly higher than present values $(\Delta \mathrm{MAP}=+235 \mathrm{~mm})$. The period of aridity during summer lasts three months (from June to August) thus well corresponding to a semi-arid Mediterranean climate.

For HAT, the overlap corresponds to some 45 UTM squares, all located in the south-westernmost Iberian Peninsula. Such a situation is partly linked to the presence of the amphisbaenian Blanus 
sp., restricted today to the Mediterranean bioclimatic area. In HAT, MAT is $16.5 \pm 2.0^{\circ} \mathrm{C}$ and MAP $750 \pm 137 \mathrm{~mm}$ (Fig. 2, Table 3). Summer is warm and winter is temperate. Rainfall is rather low with an irregular distribution over the year, mainly occurring during the winter and in a lesser amount during spring. The aridity indexes suggest a continental semi-arid Mediterranean climate with four months of dryness during the summer and the beginning of fall (Fig. 2). The comparison with the current climatic data shows that the estimated MAT for HAT are higher to present values $\left(\triangle \mathrm{MAT}=+2.6^{\circ} \mathrm{C}\right)$. The difference between the temperature of the warmest and coldest months is lower than today, due to the fact that winter temperatures are higher $\left(\triangle \mathrm{MTC}=+3.5^{\circ} \mathrm{C}\right)$ and summer $\left(\Delta \mathrm{MTW}=+1.5^{\circ} \mathrm{C}\right)$, thus suggesting a less pronounced continentality. MAPs remain low for HAT even if their total amount are slightly higher than present values $(\triangle M A P=+292 \mathrm{~mm})$. The period of aridity during summer lasts four months (from June to September) thus well corresponding to a semi-arid Mediterranean climate.

Overall paleoclimatic comparison between the studied sites, suggest two different climatic patterns: an interglacial "warmtemperate" pattern and glacial "cold" one. During relatively "warm" periods (MIS 11b, MIS 5a and today) the climate is clearly Mediterranean, with mild winters and a long period of dryness (4 months) in summer and early autumn and by contrast during "cold" periods (MIS 8 and MIS 6) the climate is more Oceanic (or continental Mediterranean), although preserving some dryness (two months) during the summer. However transitional stages may exist with sites like Valdocarros II, where summer dryness last 3 months and that seems to be rainier than the other reconstructions, with the exception of HAT that is very warm and humid.

\subsection{Paleoenvironmental data}

The distribution by habitat for each amphibian and reptile species used in this work is done in Table 4. Environmental reconstruction from the Áridos- 1 herpetofaunal assemblage during MIS 11b suggests the existence of a landscape predominantly open dry (48.5\%) with an uneven distribution of vegetation cover of scrub and forest (19.4\%), rocky and stony habitats (11.3\%) and wet meadows (9.8\%) (Fig. 3, Table 5). This deviation to a mostly dry and open environment is marked quantitatively by a significant presence of Timon lepidus, Psammodromus hispanicus and, especially, Pelobates cultripes. The lacertid T. lepidus is very adaptable but usually occurs in dry habitats, and restricts its presence on account of the existence of shelters and not by vegetation cover (Llorente et al., 1995; Díaz et al., 2006). The small lacertid P. hispanicus prefers open habitats with sparse vegetation and to a lesser extent areas of low scrub, avoiding high vegetation and forest environments (Carrascal et al., 1989; Gosá and Bergerandi, 1994). The adult toad $P$. cultripes prefers sandy or loose soils that allow it to bury itself as daytime refuge and during its periods of aestivation, but like all Iberian amphibians, also depends on the existence of water points for breeding and larval development (Recuero, 2014). The same happens to the other amphibians documented in Áridos-1 assemblage, which vary according to their adaptability to diverse terrestrial habitats as Alytes and Bufo spinosus, to humid meadows as Discoglossus galganoi and genus Hyla (Hyla molleri) or strictly aquatic as Pelophylax perezi. This last species of frog, plus the turtle Emys orbicularis, mark the presence of a fully aquatic environment (11\%) due to the proximity of the river itself. The snake Natrix natrix (sensu lato, tentatively Iberian Natrix astreptophora), which also presents aquatic trends, is mostly terrestrial, preferring wet meadows as well as, to a lesser extent, forest areas (Santos et al., 2004). The combination N. natrix, B. spinosus, D. galganoi and Hyla is consistent with the presence of wetlands, both open or with

\section{Table 4}

Distribution by habitats of the taxa recovered as fossil in the archaeopaleontological localities and of the other species represented today in the Manzanares and Jarama valleys (see Supplementary Information Table A1). Abbreviations: OD, open-dry; $\mathrm{OH}$, open-humid; WB, woodland/bush; R/S, rocky/stony environments; Wa, water-edge.

\begin{tabular}{|c|c|c|c|c|c|}
\hline \multirow[t]{2}{*}{ Species } & \multicolumn{5}{|c|}{ Habitat distribution } \\
\hline & OD & $\mathrm{OH}$ & WB & $\mathrm{R} / \mathrm{S}$ & WE \\
\hline Pleurodeles waltl & - & - & - & - & 1 \\
\hline Alytes sp. & 0.2 & 0.4 & 0.2 & - & 0.2 \\
\hline Alytes obstetricans & 0.2 & 0.4 & 0.2 & - & 0.2 \\
\hline Discoglossus galganoi & - & 0.4 & - & - & 0.6 \\
\hline Discoglossus sp. & - & 0.4 & - & - & 0.6 \\
\hline Pelobates cultripes & 0.8 & - & - & - & 0.2 \\
\hline Pelodytes punctatus & 0.5 & - & 0.2 & 0.1 & 0.2 \\
\hline Pelodytes sp. & 0.5 & - & 0.2 & 0.1 & 0.2 \\
\hline Epidalea calamita & 0.45 & - & 0.2 & 0.25 & 0.1 \\
\hline Bufo spinosus & 0.1 & 0.3 & 0.4 & - & 0.2 \\
\hline Hyla molleri & - & 0.5 & 0.2 & - & 0.3 \\
\hline Hyla sp. (meridionalis) & - & 0.6 & 0.2 & - & 0.2 \\
\hline Pelophylax perezi & - & - & - & - & 1 \\
\hline Emys/Mauremys & - & - & - & - & 1 \\
\hline Emys orbicularis & - & - & - & - & 1 \\
\hline Graptemys pseudogeographica & - & - & - & - & 1 \\
\hline Mauremys leprosa & - & - & - & - & 1 \\
\hline Pseudemys nelsonii & - & - & - & - & 1 \\
\hline Trachemys scripta & - & - & - & - & 1 \\
\hline Blanus cinereus & 0.45 & 0.1 & 0.45 & - & - \\
\hline Blanus sp. & 0.45 & 0.1 & 0.45 & - & - \\
\hline Chalcides striatus & 0.3 & 0.3 & 0.2 & 0.2 & - \\
\hline Chalcides sp. & $\mathrm{x}$ & $\mathrm{x}$ & $\mathrm{x}$ & $\mathrm{x}$ & $\mathrm{x}$ \\
\hline Tarentola mauritanica & - & - & 0.25 & 0.75 & - \\
\hline Acanthodactylus erythrurus & 0.7 & - & 0.3 & - & - \\
\hline Podarcis virescens & 0.4 & 0.1 & - & 0.5 & - \\
\hline Psammodromus algirus & 0.2 & 0.1 & 0.5 & 0.2 & - \\
\hline Psammodromus hispanicus & 0.5 & - & 0.3 & 0.2 & - \\
\hline Timon lepidus & 0.5 & - & 0.25 & 0.25 & - \\
\hline Coronella girondica & 0.25 & 0.25 & 0.25 & 0.25 & - \\
\hline Coronella sp. & 0.25 & 0.25 & 0.25 & 0.25 & - \\
\hline Macroprotodon brevis & 0.3 & 0.1 & 0.3 & 0.3 & - \\
\hline Malpolon monspessulanus & 0.35 & 0.15 & 0.25 & 0.25 & - \\
\hline Natrix maura & - & 0.2 & - & - & 0.8 \\
\hline Natrix natrix & - & 0.5 & 0.25 & - & 0.25 \\
\hline Rhinechis scalaris & 0.35 & 0.15 & 0.3 & 0.2 & - \\
\hline Vipera latastei & 0.4 & - & 0.2 & 0.4 & - \\
\hline Vipera sp. & 0.4 & - & 0.2 & 0.4 & - \\
\hline
\end{tabular}

vegetation cover. Concurrently, the presence of the snakes Rhinechis scalaris and Coronella girondica corroborates the diversity of different environments but in a dry and thermophilic general scenario (Pleguezuelos and Honrubia, 1997; Santos and Pleguezuelos, 2009).

In contrast, the Valdocarros II sequence (MIS 8/7) is characterized by a progressive increase in vegetation cover at the expense of open habitats and aquatic strictly within a warm climatic context, in correspondence with the thermophilic herpetofaunal associations. So, in level 2 the open dry habitats have still the highest values of the set (30.5\%), followed by scrubby or forested environments (25.5\%), the rocky and stony areas (16.8\%), wet meadows (14.5\%) and aquatic environments (12.6\%) (Fig. 3, Table 5). Level 3 and level 4 show very similar percentages: the habitats of scrub and forest are those with higher values in the last level (38.5\%), compared to the open dry environments (26.6\%), the rocky/stony areas (18.3\%), the wet meadows (9.9\%) and aquatic habitats (6.7\%) (Fig. 3, Table 5).

The great increase in vegetation cover matches the appearance on the regional fossil record of Psammodromus algirus, which prefers dry environments with some vegetation cover, especially thickets, avoiding open areas in contrast to P. hispanicus (Carrascal et al., 1989; Díaz and Carrascal, 1991). This species becomes more 


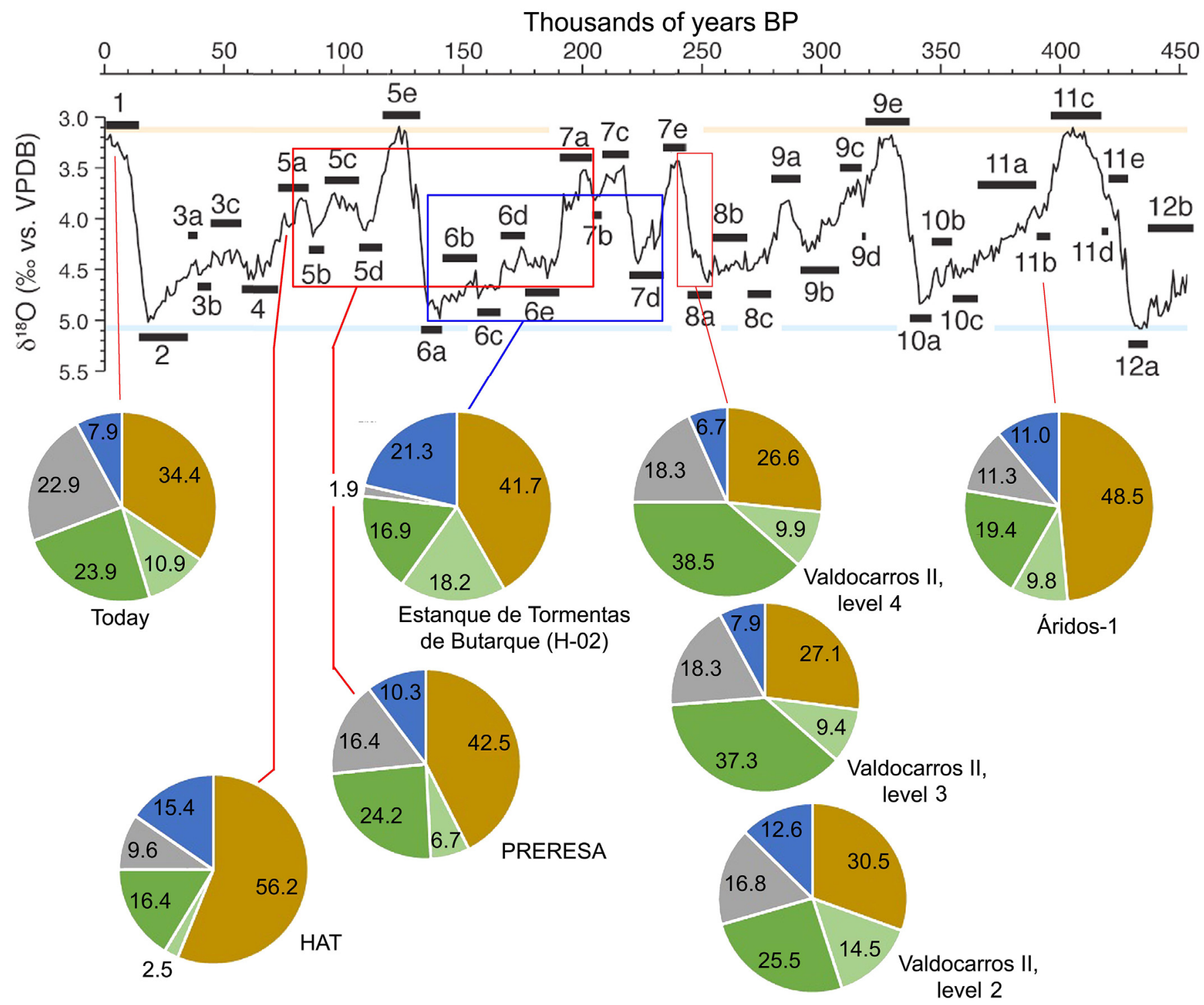

Open Dry $\square$ Open Humid $\square$ Bush / Woodland $\square$ Rocky / Stony $\square$ Water Edge

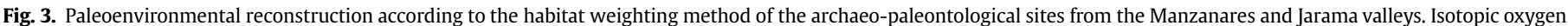
record and optimized scheme of lettered marine isotope substages from Railsback et al. (2015).

Table 5

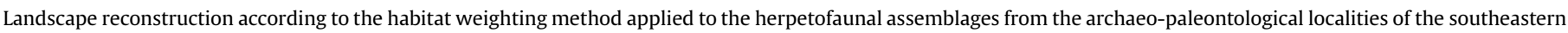
part of the Region of Madrid.

\begin{tabular}{|c|c|c|c|c|c|}
\hline & Open Dry & Open Humid & Woodland/Bush & Rocky/Stony & Water Edge \\
\hline Áridos-1 & $48.5 \%$ & $9.8 \%$ & $19.4 \%$ & $11.3 \%$ & $11.0 \%$ \\
\hline Valdocarros II, level 2 & $30.5 \%$ & $14.5 \%$ & $25.5 \%$ & $16.8 \%$ & $12.6 \%$ \\
\hline Valdocarros II, level 3 & $27.1 \%$ & $9.4 \%$ & $37.3 \%$ & $18.3 \%$ & $7.9 \%$ \\
\hline Valdocarros II, level4 & $26.6 \%$ & $9.9 \%$ & $38.5 \%$ & $18.3 \%$ & $6.7 \%$ \\
\hline ETB-H02 & $41.7 \%$ & $18.2 \%$ & $16.9 \%$ & $1.9 \%$ & $21.3 \%$ \\
\hline PRERESA & $42.5 \%$ & $6.7 \%$ & $24.2 \%$ & $16.4 \%$ & $10.3 \%$ \\
\hline HAT & $56.2 \%$ & $2.5 \%$ & $16.4 \%$ & $9.6 \%$ & $15.4 \%$ \\
\hline Present & $34.4 \%$ & $10.9 \%$ & $23.9 \%$ & $22.9 \%$ & $7.9 \%$ \\
\hline
\end{tabular}

abundant in the record with the advance of stratigraphy. This increase coincides with the decline of $P$. cultripes, reaching minimum values in MNI of all the regional sequence. Also appear for the first time on regional fossil record the genera Vipera and Pelodytes and the species Epidalea calamita, Hyla gr. H. arborea, Chalcides striatus and Natrix maura. The skink C. striatus usually prefers open habitats such as meadows, grasslands, pastures or low scrub (Pollo, 2012), although it may appears in stony zones next to the other mentioned 
areas. The snake $N$. maura is much more linked to the aquatic environment than N. natrix, absent in the Valdocarros II sequence, but also can be found in open environments near water points. The toad E. calamita, in its adult phase, presents a clear deviation towards open and well sunny environments, with sparse vegetation or lesser developed plant cover (Romero and Real, 1996). The continued association of T. lepidus, P. algirus, C. girondica, E. calamita and $P$. cultripes at all three levels of Valdocarros II shows a deviation towards dry conditions with open areas and a vegetative cover of thicket and scrubland with low development. This environmental situation is also consistent with the intermittent appearance of other taxa such as genera Alytes, Pelodytes and Vipera and species $C$. striatus and $R$. scalaris. Also, although decreasing, the fluvial influence is still noticeable with the presence of $P$. perezi and $N$. maura.

The environment documented by the herpetofauna from Estanque de Tormentas de Butarque ETB-H02, attributed to MIS 7d or MIS 6 (i.e. the Penultimate Glacial Period), shows significant changes from the previous stages, with significant increases of the aquatic environments and open moist and open dry habitats (Fig. 3, Table 5). So, the open dry environments have again the highest values (41.7\%), followed by aquatic habitats (21.3\%) and open wet environments (18.2\%), being in the latter two cases the higher values for these types of habitats throughout the whole analyzed sequence. Instead, areas of vegetation cover decay (16.9\%) while areas of rocky and stony habitats become insignificant (1.9\%).

The association of ETB-H02 consists almost exclusively by taxa related with aquatic environment, with Coronella girondica as the only terrestrial exception. It also highlights the apparent absence of more thermophilic taxa, which are typical in the previous fossil record, as T. lepidus, $R$. scalaris, P. algirus and Vipera genus, a fact that explains the very low percentage attributable to the rocky and stony habitats, as well the low values of vegetation cover environments. The taphonomical study of the remains indicates the existence of a very short transport of them and the possibility of a high percentage of in situ mortality. Therefore possibly it is a fully perifluvial association, from the closest environments to the river. Hence, there is likely a bias in the fossil assemblage from ETB-H02 that has only allowed the representation of the closest species to the river area. Or otherwise, it is also possible that the absence of thermophilic species which have been mentioned above is due to a much cooler climate, according to the glacial chronology of the level.

The herpetofaunal assemblages of HAT (MIS 5a) and PRERESA (MIS 5a or MIS 7/6), both with interglacial climatic conditions, show a general scenario of dominance of open dry habitats, although with significant differences (Fig. 3, Table 5). In HAT the prevalence of open dry environments is accentuated (56.2\%), to the detriment of open wet areas (2.5\%), vegetation cover of woods and/ or scrublands (16.4\%) and rocky zones (9.6\%). In PRERESA the open dry habitats are also predominant (42.5\%), while the remaining habitats are better represented compared to HAT (open-humid: 6.7\%; woodland: $24.2 \%$; and rocky: $16.4 \%$ ). Thermophilic Mediterranean species reappear in the fossil record, as T. lepidus, P. algirus and $V$. latastei. In addition, the genus Blanus has its first regional record in the herpetofaunal assemblage of HAT. Blanus is a legless reptile associated with warm Mediterranean environments and is adapted to underground life in loose soils with presence of stones on the surface, avoiding the most compact and clayey soils (Martín et al., 1991; López et al., 1998). The significant conjugation in the quantitative aspect of $E$. calamita and $P$. algirus in the PRERESA assemblage, in contrast to their absences in HAT, coupled with the increased representation of $V$. latastei, are consistent with the existence of greater vegetation cover of shrubby type and of refuge areas as scree. The small differences observed between PRERESA and HAT, including those related to the development of aquatic environment and wet meadows, could be explained according to the distance of these sites regarding the river.

In conclusion, the application of the method of habitat weighting on the herpetofauna currently documented in the UTM $10 \times 10 \mathrm{~km}$ squares where are located the sites under study (AHE, 2016; Supplementary Information Table A1) shows a varying scenario, with a predominance accentuated moderately of open dry environments (34.4\%), followed by habitats with vegetation cover (23.9\%) and rocky and stony areas (22.9\%), and a smaller proportion of wet meadows (10.9\%) and aquatic environments (7.9\%). The observed environmental differences with respect to the fossil record should be related to the significant impact that human activity, such as agriculture and urbanization, have had and have yet over the territory. Especially, the large representation in rocky and stony environments today that is certainly due to the large aggregate extraction activity and the proliferation of quarries on river terraces.

\subsection{Biodiversity}

The region's extraordinary environmental heterogeneity in terms of climatology, types of geological substrates, vegetation and orography contributes to there being a relatively high number of herpetofaunistic species in relation to surface area today in the Region of Madrid, with a total of 42 autochthonous species (18 amphibians and 24 reptiles) (Martínez-Solano et al., 2004). However, the southeastern part of the region, where the archaeological localities under study are located, is at a considerable distance from any major mountains and is poorer in terms of the number of herpetofaunistic species, with only 9 amphibian and 17 reptile autochthonous species (Table 2).

Throughout the different archaeological localities, the amphibians and reptiles showed different patterns for evenness and richness (Table 6). For amphibians, Simpson index (1-D) reached its highest value in the level 3 of Valdocarros II and its lowest value in the level 2 of the same locality which also held the maximum evenness value for reptiles. Minimum value for Simpson index for reptiles occurs in the level 4 of Valdocarros II.

Total values for richness, comprised between 10 and 12 species throughout the whole sequence, can be considered rather constant. However amphibians and reptiles component for richness changes between sites. For amphibians, in the level 2 of Valdocarros II where minimum value of evenness occurred, the dominant species is Pelophylax perezi. For reptiles, Psammodromus cf. algirus is the dominant species in the levels 3 and 4 of Valdocarros II where the environment is more homogeneous (Fig. 3).

When comparing this data with the modern values for Simpson index in the area, both amphibians and reptiles are under current values for evenness which are rather high (Table 6). However such result can also be the case of a certain taphonomical bias in the representation of some rare species in the archaeological sites.

Climate does not seem to be a determining factor for evenness, instead for total richness which seems to be influenced by MAP (Table 7). For reptiles, there is a high positive correlation with MAP, and vegetal cover (bush/woodland; Table 8) while for amphibians richness correlation with MAP is negative. Remaining climatic correlations have adjusted $\mathrm{r} 2$ under 0.3 or are not significant (have p-value over 0.05 ). According to the correlates, only reptiles seem to be influenced by the terrestrial environment. The percentages for forested and water-edge habitats within the whole environment are negatively correlated with reptiles' evenness and richness respectively becoming a more even and rich (in terms of number of species) assemblage when the woodland and water-edge habitats decrease. 
Table 6

Values obtained for Simpson index (evenness) and richness (number of species).

\begin{tabular}{|c|c|c|c|c|c|c|c|c|c|}
\hline & & \multirow[t]{2}{*}{ Áridos-1 } & \multicolumn{3}{|c|}{ Valdocarros II } & \multirow[t]{2}{*}{ ETB-H02 } & \multirow[t]{2}{*}{ PRERESA } & \multirow[t]{2}{*}{ HAT } & \multirow[t]{2}{*}{ Today } \\
\hline & & & level 2 & level 3 & level 4 & & & & \\
\hline \multirow{3}{*}{ Simpson Index (1-D) } & amphibians & 0.663 & 0.556 & 0.764 & 0.672 & 0.698 & 0.751 & 0.649 & 0.809 \\
\hline & reptiles & 0.718 & 0.755 & 0.448 & 0.374 & 0.64 & 0.609 & 0.736 & 0.904 \\
\hline & total & 0.846 & 0.831 & 0.604 & 0.584 & 0.820 & 0.847 & 0.815 & 0.936 \\
\hline \multirow[t]{3}{*}{ Richness (S) } & amphibians & 6 & 4 & 5 & 4 & 6 & 6 & 4 & 9 \\
\hline & reptiles & 6 & 6 & 6 & 7 & 4 & 5 & 6 & 17 \\
\hline & total & 12 & 10 & 11 & 11 & 10 & 11 & 10 & 26 \\
\hline
\end{tabular}

Table 7

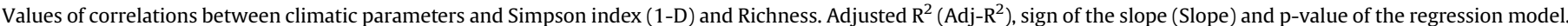

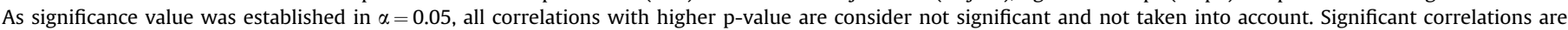
highlighted in bold.

\begin{tabular}{|c|c|c|c|c|c|c|c|c|c|c|c|c|c|}
\hline & & \multicolumn{3}{|l|}{ MAT } & \multicolumn{3}{|l|}{ MTC } & \multicolumn{3}{|l|}{ MTW } & \multicolumn{3}{|l|}{ MAP } \\
\hline & & Adj-R ${ }^{2}$ & slope & p-value & $\operatorname{Adj-R^{2}}$ & slope & p-value & Adj-R ${ }^{2}$ & slope & p-value & Adj- $R^{2}$ & slope & p-value \\
\hline \multirow[t]{3}{*}{ Simpson } & amphibians & -0.193 & + & 0.871 & -0.186 & + & 0.818 & -0.135 & + & 0.614 & -0.052 & - & 0.440 \\
\hline & reptiles & -0.191 & - & 0.850 & -0.199 & - & 0.947 & -0.162 & + & 0.702 & -0.171 & - & 0.741 \\
\hline & total & -0.168 & - & 0.725 & -0.186 & - & 0.816 & -0.176 & + & 0.762 & -0.044 & - & 0.426 \\
\hline \multirow[t]{3}{*}{ Richness } & amphibians & -0.114 & - & 0.561 & -0.186 & + & 0.818 & -0.196 & - & 0.907 & 0.586 & - & 0.027 \\
\hline & reptiles & 0.311 & + & 0.112 & 0.242 & + & 0.149 & -0.115 & + & 0.563 & 0.740 & + & 0.008 \\
\hline & total & 0.061 & + & 0.291 & 0.200 & + & 0.175 & -0.0004 & + & 0.364 & -0.198 & + & 0.927 \\
\hline
\end{tabular}

Table 8

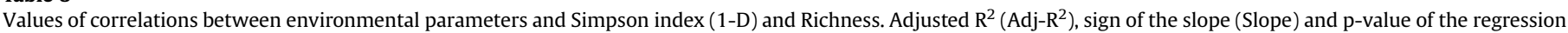

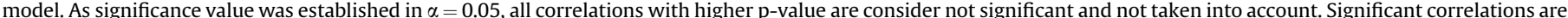
highlighted in bold.

\begin{tabular}{|c|c|c|c|c|c|c|c|c|c|c|c|c|c|c|c|c|}
\hline & & \multicolumn{3}{|c|}{ Open-dry } & \multicolumn{3}{|c|}{ Open-humid } & \multicolumn{3}{|c|}{ Woodland } & \multicolumn{3}{|l|}{ Rocky } & \multicolumn{3}{|l|}{ Water } \\
\hline & & $\overline{\operatorname{Adj}-R^{2}}$ & slope & $\overline{p \text {-value }}$ & $\overline{\mathrm{Adj}-\mathrm{R}^{2}}$ & slope & $\overline{p \text {-value }}$ & $\overline{\mathrm{Adj}-\mathrm{R}^{2}}$ & slope & $\overline{\text { p-value }}$ & $\overline{\operatorname{Adj}-R^{2}}$ & slope & $\overline{\text { p-value }}$ & $\overline{\mathrm{Adj}-\mathrm{R}^{2}}$ & slope & $\overline{p \text {-value }}$ \\
\hline \multirow[t]{3}{*}{ Simpson } & amphibians & -0.197 & - & 0.916 & -0.144 & - & 0.735 & -0.115 & + & 0.564 & -0.198 & + & 0.928 & -0.152 & - & 0.666 \\
\hline & reptiles & 0.361 & + & 0.090 & -0.200 & + & 0.980 & 0.699 & - & 0.012 & 0.062 & - & 0.291 & 0.221 & + & 0.161 \\
\hline & total & 0.407 & + & 0.073 & -0.160 & + & 0.855 & -0.196 & - & 0.903 & 0.122 & - & 0.234 & 0.249 & + & 0.145 \\
\hline \multirow[t]{3}{*}{ Richness } & amphibians & -0.103 & + & 0.536 & -0.121 & + & 0.580 & -0.043 & - & 0.425 & 0.008 & - & 0.353 & -0.115 & + & 0.564 \\
\hline & reptiles & -0.071 & - & 0.472 & 0.038 & - & 0.317 & 0.233 & + & 0.154 & 0.407 & + & 0.073 & 0.518 & - & 0.041 \\
\hline & total & -0.198 & - & 0.938 & -0.141 & - & 0.633 & -0.108 & + & 0.548 & -0.057 & + & 0.449 & 0.264 & - & 0.136 \\
\hline
\end{tabular}

\section{Discussion and conclusion}

The configuration and temporal evolution of the reconstructed habitats by the herpetofaunal assemblages suggest the existence, in the lower valleys of the Jarama and Manzanares Rivers, of a landscape with gallery forests along watercourses. Parallel to these forested areas would be the presence of wet meadows in the flood plain. Then, according to the distance from the river, they would give way, on the surrounding plateau, to shrubby and finally dry grasslands and steppe zones, with areas of scattered rocky (Fig. 4). The changes observed over the sequence could be related to the retractions of the wettest environments and the increase of dry habitats in accordance with the fluctuations of the river water regime and rainfalls. Such a situation is in accordance with the overall climate comparison between the studied sites that suggest two different climatic patterns ( + a transitional one): an interglacial "warm" pattern and a glacial "cold" one. During relatively "warm" periods (MIS 11b, MIS 7, MIS 5a and today) the climate is clearly Mediterranean, with mild winters and a long period of dryness in summer and early autumn and by contrast during "cold" periods (MIS 8 and MIS 6) the climate is more Oceanic (or continental Mediterranean), although preserving some dryness during the summer.

As far as herpetofaunal assemblages are concerned, a striking difference with modern data is the very low representation of reptiles in the archaeological localities (4-7 compared with the authochtonous 17 species currently represented in the southeastern part of the Region of Madrid): but as said before this can be due, in some way, to a taphonomical bias. At the contrary richness for anurans seems to have been quite the same (4-6 against 8 today in the area). Such pattern in biodiversity suggest 1) a quite similar diversity of anurans between cold and warm periods; 2) an impoverishment of the squamate Mediterranean fauna during cold periods (as put in evidence in ETB-H02; Blain et al., 2017); 3) an absence of any typically cold Euro-Siberian or higher altitude taxa during cold periods (i.e. brown frogs); and 4) the absence of any strong thermophilous reptile (as are today Macroprotodon brevis, Malpolon monspessulanus, Acanthodactylus erythrurus or Tarentola mauritanica) during the warm periods, even when reconstructed climate is supposed to be higher than current one.

According to the relation between richness, biodiversity and climatic and environmental factors (Tables 7 and 8), a clear correlation appears between reptile richness and woodlands. In particular in the site of Valdocarros II, it is possible to observe the dominancy of reptiles against the reconstructed percentages of woodlands. For a higher percentage of forest, reptile evenness is lower and thus dominancy is higher. In a similar way, mean annual precipitation (MAP) is revealed to be the most influent factor, certainly because of its implications on vegetal cover extension and ecosystem productivity and resources. For amphibians (here only 


\section{Glacial (Cold and dry)}

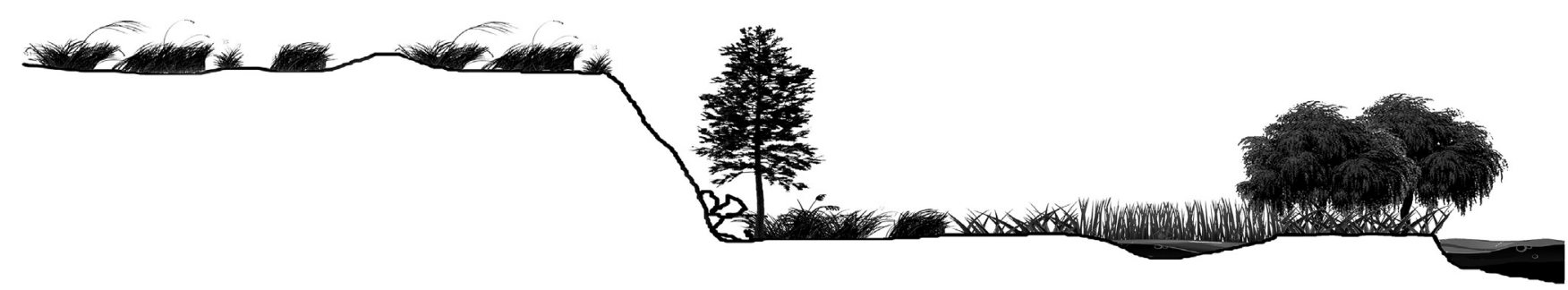

\section{Transition (Cool to temperate and humid)}
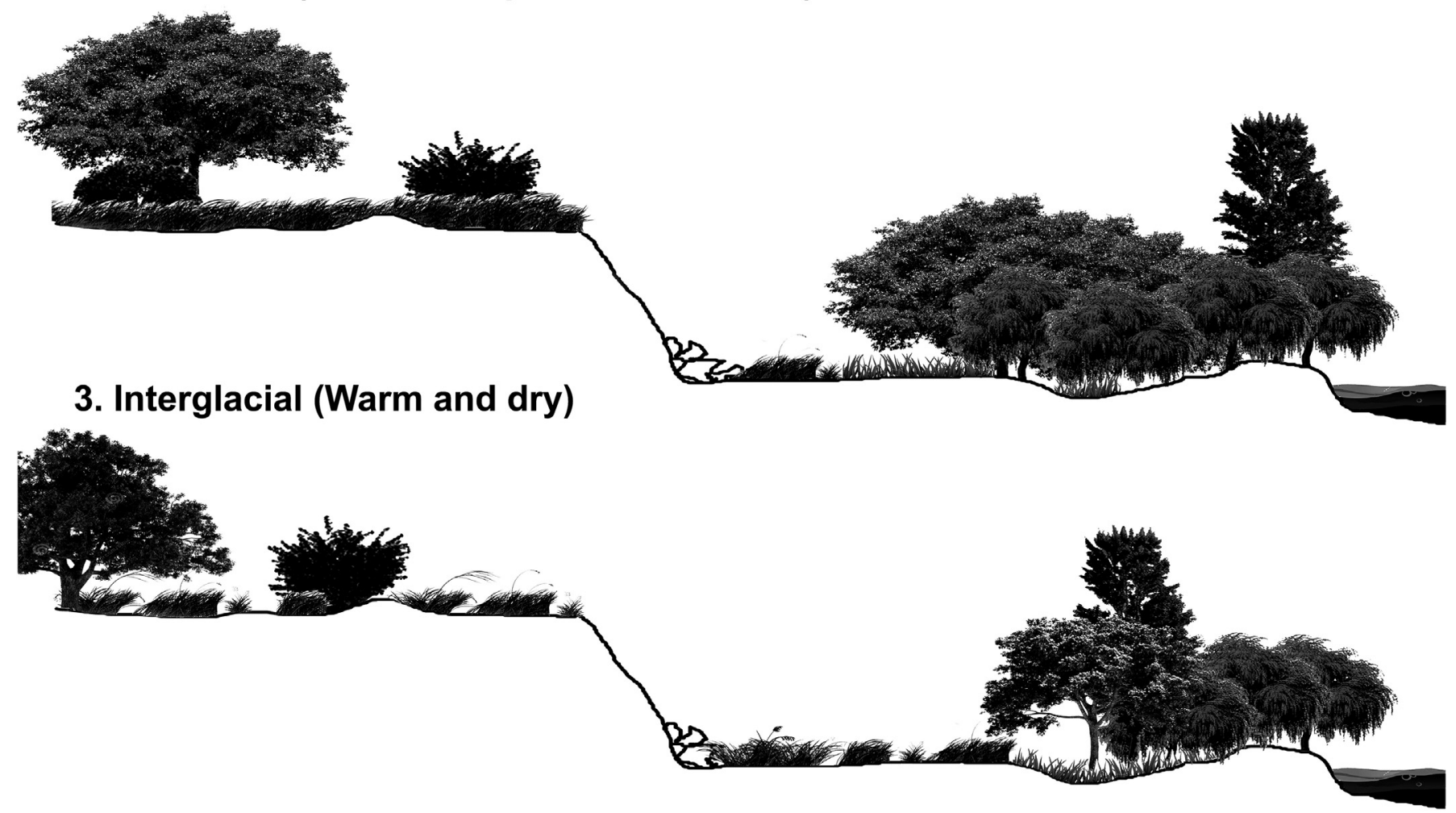
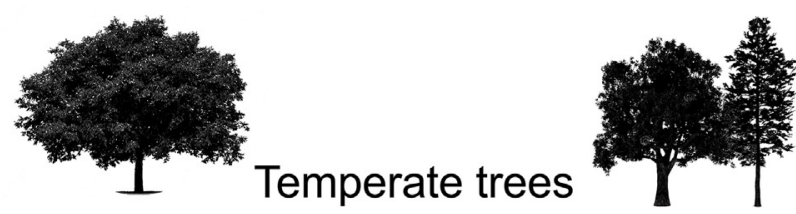

Xeric trees

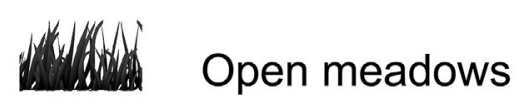

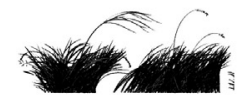

Dry meadows
Hygrophilous trees

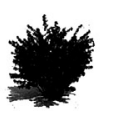

Shrubs

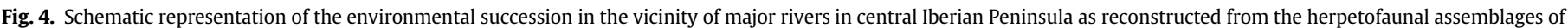

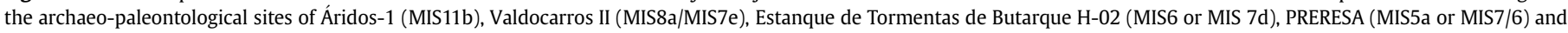
HAT (MIS5a).

anurans) the MAP does not influence dominancy but species richness: anuran richness being higher for lower MAP. Such an unusual pattern is certainly due to the fact that there are no strict forestdweller anurans within the archaeological assemblages and that most of the anurans present in the site are well adapted to arid conditions. However even if the correlation rank is high, variation among richness values is rather low (comprised between 4 and 6; Table 6) and thus it can be considered that there is not a lot of differences.
For reptiles, MAP is the most influent parameter on species richness (Table 7). In this case the relation is positive, with a higher number of species for higher MAP. Even if the variation rank of the values is low (comprised between 7 and 4), the adjustment degree is higher than for amphibians. This fit quite well with the relation between the Simpson's Index and the percentage of woodland (Table 8), thus suggesting that for a higher MAP, woodland are more represented in the area together with higher resources and ecological niches. In that way, the ecosystem can support a higher 
number of species with a species succession reaching a more evolved state (climax) favoring the possible dominancy of one of the species and thus leading to a decrease of the Simpson's Index. A clear example of dominancy is visible in the levels 3 and 4 of Valdocarros II (Table 2), where the dominant species is the lizard Psammodromus cf. algirus (reaching in both cases more than $60 \%$ of the whole association). Today, the abundance of that species is positively correlated with bush cover (over $20 \mathrm{~cm}$ high) and with food availability; parameters also correlated with vegetal cover and the presence of leaves litter on the ground (Díaz and Carrascal, 1991). In the Region of Madrid meadow environments, its abundance is higher for a higher representation of scrub covering (Martín and López, 2002), reaching up to 13-18 individuals per hectare in holm oak forest ("encinares") (Cano, 1984), or between 30 and 22.5 adults per hectare in oak forest ("robledales") (Díaz, 1993). In the surrounding mountain environments Psammodromus cf. algirus has been reported to reach much higher densities up to 130 specimens per hectare in the Sierra de Guadarrama (Salvador and Veiga, 2001) and up to 178 individuals per hectare in the Sierra de Gredos (Gil Costa, 1992). In a same way a higher vegetal cover (low scrubs) has been showed to be highly correlate with the survival rates of newborns (Civantos et al., 1999).

Taking as a reference the modern situation in the area, the successive herpetofaunal assemblages from Áridos-1 (MIS11b), Valdocarros II (MIS8a/MIS7e), Estanque de Tormentas de Butarque H-02 (MIS6 or MIS7d), PRERESA (MIS5a or MIS 7/6) and HAT (MIS5a) permits a hypothetical landscape reconstruction as represented in Fig. 4. Three different periods are then represented with a glacial landscape (ETB-H02; Fig. 4.1), a landscape of transition from cool to temperate climatic conditions (Valdocarros II; Fig. 4.2), and an interglacial landscape (Áridos-1, HAT, PRERESA and today; Fig. 4.3). Environment is particularly open during dry periods (independently of if it is cold or warm) with a percentage of open-dry environment about $40 \%$. The main difference between an interglacial and a glacial period is the opposite representation of woodlands vs. moist environments (water-edge + open-humid): the last ones being more represented during cold periods than during warm periods. Finally, as documented by the succession from Valdocarros II (from level 2 to level 4), periods of transition between a cold and warm climate are more forested (40\% of the total landscape) but at the expense of humid meadows progressively.

As a conclusion, even if highly hypothetical and waiting for a confirmation by pollen studies, such landscape reconstructions may serves as a general background to put into context the large mammalian fauna represented in each sites as well as the hominin activities along water courses in central Iberian Peninsula.

\section{Acknowledgments}

This paper is part of projects CGL2016-80000-P of the Spanish Ministry of Economy and Competitiveness and 2017 SGR-859 of the Government of Catalonia (AGAUR Agency). J.F. Bisbal-Chinesta is supported by a FI Predoctoral Fellowship (2016FI_B00286) with the financial sponsorship of the Agència de Gestió d'Ajuts Universitaris i de Recerca (AGAUR) and the Departament d'Empresa i Coneixement of the Generalitat de Catalunya. Authors thanks Salvador Bailon (Muséum national d'Histoire naturelle, Paris, France) and César Laplana Conesa (Museo Arqueológico Regional de la Comunidad de Madrid, Alcalá de Henares, Spain) for their comments on the manuscript.

\section{Appendix A. Supplementary data}

Supplementary data related to this article can be found at https://doi.org/10.1016/j.quaint.2018.03.004.

\section{References}

Alia, M., 1960. Sobre la tectónica profunda de la fosa del Tajo. Notas y Comunicaciones del Instituto Tecnológico y Geominero de España 58, 125-162.

Asociación Herpetológica Española, 2016. Servicio de Información de Anfibios y Reptiles de España. Dirección General de Medio Natural y Política Forestal Asociación Herpetologica Española. http://www.siare.herpetologica.es/ [Date of access: 5 September 2016].

Barquero, J.A., 2001. El Control del Comercio y las Especies Potencialmente Invasoras: Situación Actual de la Tortuga de Florida (Trachemys scripta elegans) en España. Memoria de Máster. Universidad Internacional de Andalucía.

Beaulieu de, J.L., Andrieu-Ponel, V., Reille, M., Grügerb, E., Tzedakis, C., Svobodova, H., 2001. An attempt at correlation between the Velay pollen sequence and the Middle Pleistocene stratigraphy from central Europe. Quat. Sci. Rev. 20, 1593-1602.

Blain, H.-A., Bailon, S., 2010. Anfibios y escamosos del Pleistoceno inferior de Barranco León y de Fuente Nueva 3 (Orce, Andalucía, España). In: Toro, I., MartínezNavarro, B., Agustí, J, Coords (Eds.), Ocupaciones humanas durante el Pleistoceno inferior y medio de la Cuenca de Guadix-Baza. Arqueología Monografías. Junta de Andalucía, Sevilla, pp. 165-183.

Blain, H.-A., Bailon, S., Cuenca-Bescós, G., 2008. The Early-Middle Pleistocene palaeoenvironmental change based on the squamate reptile and amphibian proxy at the Gran Dolina site, Atapuerca, Spain. Palaeogeogr. Palaeoclimatol. Palaeoecol. 261, 177-192.

Blain, H.-A., Bailon, S., Cuenca-Bescós, G. Arsuaga, J.L, Bermúdez de Castro, J.M., Carbonell, E., 2009. Long-term climate record inferred from Early-Middle Pleistocene amphibian and squamate reptile assemblages at the Gran Dolina cave, Atapuerca, Spain. J. Hum. Evol. 56, 55-65.

Blain, H.-A., Bailon, S., Agustí, J., Martínez-Navarro, B., Toro, I., 2011. Paleoenvironmental and paleoclimatic proxies to the Early Pleistocene hominids of Barranco León D and Fuente Nueva 3 (Granada, Spain) by means of their amphibian and reptile assemblages. Quat. Int. 243, 44-53.

Blain, H.-A., Sesé, C., Panera, J., Rubio-Jara, S., Uribelarrea, D., Pérez-González, A., 2012a. Paleoclimatic and paleoenvironmental proxies to the Marine Isotope Stage 7e (Middle Pleistocene) in central Spain (Valdocarros II, Madrid) by means of the small-vertebrate assemblages. In: International Conference. European Middle Palaleolithic during MIS 8-MIS 3. Cultures-environment-chronology, Wolbrom, Poland, pp. 77-78. September 25th-28th.

Blain, H.-A., Panera, J., Uribelarrea, D., Rubio-Jara, S., Pérez-González, A., 2012b. Characterization of a rapid climate shift at the MIS 8/7 transition in central Spain (Valdocarros II, Autonomous Region of Madrid) by means of the herpetological assemblages. Quat. Sci. Rev. 47, 73-81.

Blain, H.-A., Sesé, C., Rubio-Jara, S., Panera, J., Uribelarrea, D., Pérez-González, A. 2013. Reconstitution paléoenvironnementale et paléoclimatique du Pléistocène supérieur ancien (MIS 5a) dans le Centre de l'Espagne: les petits vertébrés (Amphibia, Reptilia \& Mammalia) des gisements de HAT et PRERESA (Sud-est de Madrid). Quaternaire 24, 191-205.

Blain, H.-A., Santonja, M., Pérez-González, A., Panera, J., Rubio-Jara, S., 2014. Climate and environments during Marine isotope stage 11 in the central Iberian Peninsula: the herpetofaunal assemblage from the Acheulean site of Áridos-1. Madrid. Quaternary Science Reviews 94, 7-21.

Blain, H.-A., Lozano-Fernández, I., Ollé, A., Rodríguez, J., Santonja, M., PérezGonzález, A., 2015. The continental record of Marine isotope stage 11 (Middle pleistocene) on the Iberian Peninsula characterized by the herpetofaunal assemblages. J. Quat. Sci. 30, 667-678.

Blain, H.-A., Lozano-Fernández, I., Agustí, J., Bailon, S., Menéndez, L., Espígares Ortiz, M.P., Ros-Montoya, S., Jiménez Arenas, J.M., Toro, I., Martínez-Navarro, B., Sala, R., 2016. Refining upon the climatic background of the early pleistocene hominid settlement in western Europe: Barranco León and Fuente Nueva-3 (Guadix-Baza basin, SE Spain). Quat. Sci. Rev. 144, 132-144.

Blain, H.-A., Rubio-Jara, S., Panera, J., Uribelarrea, D., Laplana, C., Herráez, E., PérezGonzález, A., 2017. A new Middle pleistocene (Marine isotope stage 6) cold herpetofaunal assemblage from the central Iberian Peninsula (Manzanares Valley, Madrid). Quat. Res. 87, 499-515.

Cano, J., 1984. La comunidad de lacértidos (Lacertidae: Squamata) de un encinar continental. Ciclo anual de actividad. M.D. Thesis. Universidad Complutense, Madrid, Spain.

Carrascal, L.M., Salvador, A. (Eds.), 2002-2016. Enciclopedia Virtual de los Vertebrados Españoles. Museo Nacional de Ciencias Naturales, Madrid. http://www, vertebradosibericos.org/.

Carrascal, L.M., Díaz, J.A., Cano, C., 1989. Habitat selection in Iberian Psammodromus species along a Mediterranean successional gradient. Amphibia-Reptilia 10, $231-242$.

Civantos, E., Salvador, A., Veiga, J.P., 1999. Body size and microhabitat affect winter survival of hatchling Psammodromus algirus lizards. Copeia 1999, 1116-1121.

Desprat, S., Sánchez Goñi, M.F., McManus, J., Duprat, J., Cortijo, E., 2009. Millennial scale climatic variability between 340.000 and 270.000 years ago in SW Europe: evidence from a NW Iberian margin pollen sequence. Clim. Past 5, $53-72$.

Díaz, J.A., 1993. Breeding coloration, mating opportunities, activity, and survival in the lacertid lizard Psammodromus algirus. Can. J. Zool. 71, 1104-1110.

Díaz, J.A., Carrascal, L.M., 1991. Regional distribution of a Mediterranean lizard: influence of habitat cues and prey abundance. J. Biogeogr. 18, 291-297.

Díaz, J.A., Monasterio, C., Salvador, A., 2006. Abundance, microhabitat selection and 
conservation of eyed lizards (Lacerta lepida): a radiotelemetric study. J. Zool. 268, 295-301.

Domínguez-Alonso, R.M., Arcos Fernández, S., Ruiz Zapata, B., Gil García, M.J., 2009. Nuevos datos sobre la Terraza compleja de Butarque en Villaverde Bajo. Actas de las IV Jornadas de Patrimonio Arqueológico de la Comunidad de Madrid (2007). CARM, Madrid, pp. 339-343.

Fletcher, W.J., Müller, U.C., Koutsodendris, A., Christanis, K., Pross, J., 2013. A centennial-scale record of vegetation and climate variability from 312 to 240 ka (Marine Isotope Stages 9c-a, 8 and 7e) from Tenaghi Philippon, NE Greece. Quat. Sci. Rev. 78, 108-125.

Foury, Y., Desclaux, E., Daujeard, C., Defleur, A., Moncel, M.H., Raynal, J.P., 2016. Évolution des faunes de rongeurs en moyenne vallée du Rhône (Rive droite, Ardèche, France) au cours du Pléistocène Moyen final et du Pléistocène Supérieur ancien, du MIS6 au MIS4. Quaternaire 27 (1), 55-79.

García-París, M., Montori, A., Herrero, P., 2004. Amphibia. Lissamphibia. In: Ramos, M.A., et al (Eds.), Fauna Ibérica, vol. 24. Museo Nacional de Ciencias Naturales, Madrid, pp. 1-640.

Gil Costa, M., 1992. Estudio de la comunidad de saurios de la vertiente meridional de la Sierra de Gredos. PhD Thesis. Universidad de Salamanca, Spain.

Godinho, R., Teixeira, J., Rebelo, R., Segurado, P., Loureiro, A., Álvares, F., Gomes, N., Cardoso, P., Camilo-Alves, C., Brito, J.C., 1999. Atlas of the continental Portuguese herpetofauna: an assemblage of published and new data. Rev. Espanola Herpetol. 13, 61-82.

Gosá, A., Bergerandi, A., 1994. Atlas de distribución de los anfibios y reptiles de Navarra. Munibe 46, 109-189.

Goy, J.L., Pérez-González, A., Zazo, C., 1989. Cartografía geológica del Cuaternario, geomorfología y Memoria correspondiente de la Hoja a E, 1: 50.000 de Madrid (559). Instituto Tecnológico Geológico y Minero de España, Madrid.

Hammer, O., Harper, D.A.T., Ryan, P.D., 2001. PAST: paleontological Statistical software for education and data analysis. Palaeontol. Electron. 4, 1-9.

Laplana, C., Herráez, E., Yravedra Saínz de los Terreros, J., Bárez, S., Rubio-Jara, S., Panera, J., Rus, I., Pérez-González, A., 2015. Biocronología de la Terraza Compleja de Butarque del río Manzanares en el Estanque de Tormentas al sur de Madrid (España). Estud. Geol. 71 (1), 1-16.

Llorente, G.A., Montori, A., Santos, X., Carretero, M.A., 1995. Atles de distribució dels Amfibis i Rèptils de Catalunya i Andorra (El Grau, Figueres).

López, P., Salvador, A., Martín, J., 1998. Soil temperatures, rock selection and the thermal ecology of the amphisbaenian reptile Blanus cinereus. Can. J. Zool. 76, 673-679.

López Martínez, N., 1980. Los micromamíferos (Rodentia, Insectivora, Lagomorpha Chiroptera), del sitio de ocupación Achelense de Áridos 1-1 (Arganda, Madrid). In: Santonja, M., López Martínez, N., Pérez-González, A. (Eds.), Ocupaciones Achelenses en el Valle del Jarama (Arganda, Madrid) Arqueología y Paleoecología, pp. 161-202, 1. Diputación Provincial de Madrid.

Magurran, A.E., McGill, B.J. (Eds.), 2011. Biological Diversity - Frontiers in Measurement and Assessment. Oxford University Press, Oxford.

Martín, J., López, P., 2002. The effect of Mediterranean dehesa management on lizard distribution and conservation. Biol. Conserv, 108, 213-219.

Martín, J., López, P., Salvador, A., 1991. Microhabitat selection of the amphisbaenian Blanus cinereus. Copeia 1991, 1142-1146.

Martínez-Solano, Í., Bosch, J., García-París, M., 2004. Madrid. In: Pleguezuelos, J.M., Márquez, R., Lizana, M. (Eds.), Atlas y Libro Rojo de los Anfibios y Reptiles de España. Dirección General de Conservación de la Naturaleza- Asociación Herpetologica Española, Madrid, p. 471.

Mingot, D., López-Rodrigo, J., Ordóñez-Rivas, C., Sobrino, E., 2003. Reproducción en libertad del galápago de Florida (Trachemys scripta elegans) en el centro de la península ibérica. Bol. Asoc. Herpetol. Espanola 14, 39-43.

Moreno, D., Duval, M., Rubio-Jara, S., Panera, J., Bahain, J.J., Shao, Q., PérezGonzález, A., Falguères, C., 2018. ESR Dating of Several Middle to Late Pleistocene Archaeo-paleontological Sites from the Manzanares and Jarama River Valleys (Madrid Basin, Spain). Quaternary International. https://doi.org/10.1016/ j.quaint.2017.09.003.

Ninyerola, M., Pons, X., Roure, J.M., 2005. Atlas Climático Digital de la Península Ibérica. Metodología y Aplicaciones en Bioclimatología y Geobotánica. Universidad Autónoma de Barcelona, Bellaterra, Spain.

Panera, J., Pérez-González, A., Rubio Jara, S., Sesé, C., 2005. El yacimiento paleolítico de Hat en el valle del Jarama : una aportación de Cuaternario de la cuenca de Madrid al debate sobre el inicio del Paleolítico medio. In: Santonja, M., PérezGonzález, A., Machado, M.J. (Eds.), Geoarqueologia y Patrimonio en la Peninsula Iberica y el entorno Mediterraneo. ADEMA, Soria, pp. 251-260.

Panera, J., Torres, T., Pérez-González, A., Ortiz, J.E., Rubio-Jara, S., Uribelarrea, D., 2011. Geocronología de la Terraza Compleja de Arganda en el valle del río Jarama (Madrid, España). Estud. Geol. 67 (2), 495-504.

Panera, J., Rubio-Jara, S., Yravedra, J., Blain, H.-A., Sesé, C., Pérez-González, A., 2014. Manzanares valley (Madrid, Spain): a good country for Proboscideans and Neanderthals. Quat. Int. 326, 329-343.

Pérez-González, A., 1971. Estudio de los procesos de hundimiento en el valle del río Jarama y sus terrazas (nota preliminar). Estud. Geol. XXVII (4), 317-324.

Pérez-González, A., 1980. Geología y estratigrafía de los yacimientos de Áridos en la llanura aluvial de Arganda (Madrid). In: Santonja, M., López, N., PérezGonzález, A. (Eds.), Ocupaciones achelenses en el valle del Jarama. Arqueología y Paleontología, I. Diputación Provincial de Madrid, pp. 49-61.

Pérez-González, A., 1994. In: Elorza, Gutiérrez (Ed.), Depresión del Tajo. Geomorfología de España, Rueda, pp. 389-436.

Pérez-González, A., Uribelarrea del Val, D., 2002. Geología del Cuaternario de los valles fluviales del Jarama y Manzanares en las proximidades de Madrid. In: Panera, J., Rubio-Jara, S. (Eds.), Bifaces y elefantes. La investigación del Paleolítico Inferior en Madrid, pp. 303-317. Zona Arqueológica, vol. 1.

Pérez-González, A., Gallardo-Millán, J.L., Uribelarrea del Val, D., Panera, J., RubioJara, S., 2013. La inversión Matuyama-Brunhes en la secuencia de terrazas del río Jarama entre Velilla de San Antonio y Altos de la Mejorada, al SE de Madrid (España). Estud. Geol. 69 (1), 35-46.

Pérez-González, A., Rubio-Jara, S., Panera, J., Uribelarrea, D., 2008. Geocronología de la sucesión arqueoestratigráfica de Los Estragales en la Terraza Compleja de Butarque (Valle del río Manzanares, Madrid). Geogaceta 45, 39-42.

Pleguezuelos, J.M., 2004. Las especies introducidas de anfibios y reptiles. In: Pleguezuelos, J.M., Márquez, R., Lizana, M. (Eds.), Atlas y Libro Rojo de los Anfibios y Reptiles de España. Dirección General de la Conservación de la Naturaleza-Asociación Herpetológica Española, Madrid, pp. 501-532.

Pleguezuelos, J.M., Honrubia, S., 1997. La culebra de escalera. In: Pleguezuelos, J.M. Martínez-Rica, J.P. (Eds.), Distribución y Biogeografía de los anfibios y reptiles de España y Portugal, pp. 264-266. Monografías de la Revista Española de Herpetología 3.

Pleguezuelos, J.M., Martínez-Rica, J.P., 1997. Distribución y Biogeografia de los anfibios y reptiles de España. In: Pleguezuelos, J.M., Martínez-Rica, J.P. (Eds.) Distribución y Biogeografía de los anfibios y reptiles de España y Portugal, p. 542. Monografías de la Revista Española de Herpetología 3.

Pleguezuelos, J.M., Márquez, R., Lizana, M. (Eds.), 2004. Atlas y Libro Rojo de los Anfibios y Reptiles de España. Dirección General de Conservación de la Naturaleza- Asociación Herpetologica Española, Madrid, p. 587.

Pollo, C.J., 2012. Eslizón tridáctilo ibérico - Chalcides striatus. In: Salvador, A. Marco, A. (Eds.), Enciclopedia Virtual de los Vertebrados Españoles. Museo Nacional de Ciencias Naturales, Madrid. http://www.vertebradosibericos.org/ [consultation: 4 september 2016].

Railsback, L.B., Gibbard, P.L., Head, M.J., Voarintsoa, N.R.G., Toucanne, S., 2015. An optimized scheme of lettered marine isotope substages for the last 1.0 million years, and the climatostratigraphic nature of isotope stages and substages. Quat. Sci. Rev. 111, 94-106.

Recuero, E., 2014. Sapo de espuelas - Pelobates cultripes. In: Salvador, A. Martínez Solano, I. (Eds.), Enciclopedia Virtual de los Vertebrados Españoles. Museo Nacional de Ciencias Naturales, Madrid. http://www.vertebradosibericos.org/ [Date of access: 3 September 2016].

Recuero, E. Iraola, A., Rubio, X., Machordom, A., García-París, M., 2007. Mitochondrial differentiation and biogeography of Hyla meridionalis (Anura: Hylidae): an unusual phylogeographical pattern. J. Biogeogr. 34, 1207-1219.

Reille, M., de Beaulieu, J-L., 1995. Long pleistocene pollen records from the Praclaux Crater, South-Central France. Quat. Res. 44, 205-215.

Reille, M., Andrieu, V., de Beaulieu, J.-L., Guenet, P., Goeury, C., 1998. A long pollen record from Lac du Bouchet, Massif Central, France: for the period ca 325 to 100 ka BP (OIS 9c to OIS 5e). Quat. Sci. Rev. 17, 1107-1123.

Reille, M., de Beaulieu, J.L., Svobodova, H., Andrieu-Ponel, V., Goeury, C., 2000. Pollen stratigraphy of the five last climatic cycles in a long continental sequence from Velay (Massif Central, France). J. Quat. Sci. 15, 665-685.

Romero, J., Real, R., 1996. Macroenvironmental factors as ultimate determinants of distribution of common toad and natterjack toad in the south of Spain. Ecog raphy $19,305-312$.

Roucoux, K.H., Tzedakis, P.C., de Abreu, L., Shackleton, N.J., 2006. Climate and vegetation changes 180,000 to 345,000 years ago recorded in a deep-sea core off Portugal. Earth Planet Sci. Lett. 249, 307-325.

Rubio-Jara, S., 2011. El paleolítico en el valle del río Manzanares (Madrid) Caracterización Geoarqueológica de Depósitos Pleistocenos y Estudio Tecnoeconómico de la industria lítica (Unpublished PhD thesis). Universidad Nacional de Educación a distancia (UNED).

Rubio-Jara, S., Panera, J., Rodríguez de Tembleque, J., Santonja, M., Pérez González, A., 2016. Large flake Acheulean in the middle of Tagus basin (Spain) middel stretch of the river Tagus valley and lower stretches of the rivers Jarama and Manzanares valleys. Quat. Int. 411, 349-366.

Sadori, L., Koutsodendris, A., Panagiotopoulos, K., Masi, A., Bertini, A., CombourieuNebout, N., Francke, A., Kouli, K., Joannin, S., Mercuri, A.M., Peyron, O., Torri, P. Wagner, B., Zanchetta, G., Sinopoli, G., Donders, T.H., 2016. Pollen-based paleoenvironmental and paleoclimatic change at Lake Ohrid (south-eastern Europe) during the past $500 \mathrm{ka}$. Biogeosciences 13, 1423-1437.

Salvador, A., 1997. Reptiles. In: Ramos, M.A., et al. (Eds.), Fauna Ibérica, vol. 10. Museo Nacional de Ciencias Naturales, Madrid, pp. 1-705.

Salvador, A., Veiga, J.P., 2001. Male traits and pairing success in the lizard Psam modromus algirus. Herpetologica 57, 77-86.

Santos, X., Pleguezuelos, J.M., 2009. Culebra lisa meridional - Coronella girondica. In: Salvador, A., Marco, A. (Eds.), Enciclopedia Virtual de los Vertebrados Españoles. Museo Nacional de Ciencias Naturales, Madrid. http://www vertebradosibericos.org/ [Date of access: 3 September 2016]

Santos, X., Llorente, G.A., Montori, A., Carretero, M.A., 2004. Natrix natrix Linnaeus (1758) Culebra de collar. In: Pleguezuelos, J.M., Márquez, R., Lizana, M. (Eds.), Atlas y Libro Rojo de los Anfibios y Reptiles de España. Ministerio de Medio Ambiente, Madrid, pp. 293-295.

Sesé, C., Soto, E., 2000. Vertebrados del Pleistoceno de Madrid. In: Morales, J. (Ed.) (Coord.). Patrimonio paleontológico de la Comunidad de Madrid. Comunidad de Madrid, pp. 215-243. Arqueología, Paleontología y Etnografía 6.

Sesé, C. Panera, J., Rubio-Jara, S., Pérez-González, A., 2011. Micromamíferos del Pleistoceno Medio y Pleistoceno Superior en el Valle del Jarama: Yacimientos de Valdocarros y HAT (Madrid). Estud. Geol. 67 (1), 131-151. 
Silva, P., Goy, J.L., Zazo, C., 1988a. Neotectónica del sector centro-meridional de la Cuenca de Madrid. Estud. Geol. 2, 133-136.

Silva, P.G., Goy, J.L., Zazo, C., Hoyos, M., Alberdi, M.T., 1988b. El valle del Manzanares y su relación con la depresión Prados-Guaten durante el Pleistoceno inferior (Madrid, España). II Congreso geológico de España. Comunicaciones 1 (Granada, 1988), 403-406.

Silva, P.G., López-Recio, M., González Hernández, F.M., Tapias, F., Alarcón, A., Cuartero, F., Expósito, A., Lázaro, I., Manzano, I., Martín, D., Morín, J., Yravedra, J., 2008. Datos geoarqueológicos de la terraza compleja del Manzanares entre el sector del 12 de Octubre y la desembocadura del arroyo Butarque (Villaverde, Madrid). Cuaternario Geomorfol. 22, 47-70.

Silva, P.G., Tapias, F., López-Recio, M., Carrasco, P., Morín, J., Roquero, E., Rus, I., 2011. Análisis Estratigráfico del arenero de Arriaga (Terraza compleja del Manzanares, Madrid). Resúmenes XIII Reunión Nacional de Cuaternario, Andorra, 2011.

Silva, P.G., López-Recio, M., Cuartero, F., Baena, J., Tapias, F., Manzano, I., Martín, D. Morín, J., Roquero, E., 2012. Contexto geomorfológico y principales rasgos tecnológicos de nuevos yacimientos del Pleistoceno Medio y Superior en el Valle Inferior del Manzanares (Madrid, España). Estud. Geol. 68, 58-89.

Silva, P.G., López-Recio, M., Tapias, F., Roquero, E., Morín, J., Rus, I., CarrascoGarcía, P. Giner-Robles, J.L., Rodríguez-Pascua, M.A., Pérez-López, R., 2013. Stratigraphy of the Arriaga Palaeolithic sites. Implications for the geomorphological evolution recorded by thickened fluvial sequences within the Manzanares River Valley (Madrid Neogene Basin, Central Spain). Geomorphology $196,138-161$.
Simpson, E.H., 1949. Measurement of diversity. Nature 163, 688.

Tzedakis, P.C., 1993. Long term tree populations in northwest Greece through multiple quaternary climatic cycles. Nature 364, 437-440.

Tzedakis, P.C., 1994. Hierarchical biostratigraphical classification of long pollen sequences. J. Quat. Sci. 9, 257-259.

Tzedakis, P.C., Andrieu, V., de Beaulieu, J.-L., Crowhurst, S., Follieri, M., Hooghiemstra, H., Magri, D., Reille, M., Sadori, L., Shackleton, N.J., Wijmstra, T.A., 1997. Comparison of terrestrial and marine records of changing climate of the last 500,000 years. Earth Planet Sci. Lett. 150, 171-176.

Tzedakis, P.C., McManus, J.F., Hooghiemstra, H., Oppo, D.W., Wijmstra, T.A., 2003. Comparison of changes in vegetation in northeast Greece with records of climate variability on orbital and suborbital frequencies over the last 450,000 years. Earth Planet Sci. Lett. 212, 197-212.

Tzedakis, P.C., Hooghiemstra, H., Pälike, H., 2006. The last 1.35 million years at Tenaghi Philippon: revised chronostratigraphy and long-term vegetation trends. Quat. Sci. Rev. 25, 3416-3430.

Valdeolmillos-Rodríguez, A., Dorado-Valiño, M., Ruiz-Zapata, M.B., AlonsoZarza, A.M., 2011. Middle Pleistocene variations in palaeoclimate, palaeoenvironment and vegetation of the Las Tablas de Daimiel National Park (Spain). J. Quat. Sci. 26, 128-140.

Yravedra, J., Rubio-Jara, S., Panera, J., Uribelarrea, D., Pérez-González, A., 2012. Elephants and subsistence. Evidence of the human exploitation of extremely large mammal bones from the Middle Palaeolithic site of PRERESA (Madrid, Spain). J. Archaeol. Sci. 39, 1063-1071. 